\title{
Na gruzach imperium. Ukraina po upadku cesarstwa rosyjskiego: od rewolucji lutowej 1917 do traktatu brzeskiego 1918
}

\section{UKRAIŃSKA CENTRALNA RADA. LUDZIE I SPRAWY}

Zaledwie car abdykował i dopiero co powstał Rząd Tymczasowy'1 ${ }^{1}$ a już 4/17 marca 1917 r. utworzono w Kijowie Ukraińską Centralną Radę ${ }^{2}$ Tak oto na powierzchnię życia politycznego na Ukrainie błyskawicznie wyszedł ruch narodowy, bazujący zresztą na politykach o dość zróżnicowanych opcjach społecznych z wyraźną przewagą inteligencji socjaldemokratycznej: socjaldemokraci bliscy mienszewikom, socjaliści-rewolucjoniści (eserowcy ${ }^{3}$ ), socjaliści-federaliści, demokra-

\footnotetext{
1 Między Komitetem Wykonawczym Rady Piotrogrodzkiej a Komitetem Tymczasowym Dumy, przekształcającym się właśnie w Rząd Tymczasowy, zawarte zostało porozumienie. W nocy z 1 na 2 marca 1917 r. strony wynegocjowały ośmiopunktowy program, który miał być realizowany przez rząd do chwili zwołania Zgromadzenia Ustawodawczego: 1) amnestia dla więźniów politycznych; 2) wolność słowa, zrzeszeń i zgromadzeń oraz prawo do strajku; 3) likwidacja różnic prawnych z uwagi na narodowość, religię, pochodzenie społeczne; 4) zwołanie Zgromadzenia Konstytucyjnego wybranego w wyborach powszechnych, równych, bezpośrednich, w głosowaniu tajnym; 5) rozwiązanie wszelkich instytucji policyjnych i zastąpienie ich milicją nadzorowaną przez samorządy; 6) powołanie nowych samorządów lokalnych w wyborach powszechnych, równych, bezpośrednich, w głosowaniu tajnym; 7-8) [...]. Tekst polski deklaracji Rządu Tymczasowego o jego składzie i zadaniach z 3 marca 1917 r. zob. m.in. [w:] Historia państwa i prawa. Wybór tekstów źródlowych, red. B. Lesiński, Poznań 1995, s. 258-259; zob. też R. Pipes, Czerwone imperium. Powstanie Zwiazkи Sowieckiego, tłum. W. Jeżewski, Warszawa 2015, s. 237; И.А. Исаев, История государства и права России, 4-е издание, Москва 2016, s. 538; История отечественного государства и права, ч. 1, Ред. О. И. Чистяков, Москва 2006, s. 440.

${ }^{2}$ Історія держави і права Украӥни. Академічний курс, t. 2, Ред. В. Й. Тацій, А. Й. Порожин, Київ 2000, s. 39; История отечественного государства и права..., ч. 1, s. 455.

${ }^{3}$ Socjaliści-Rewolucjoniści (SR - eserowcy) - radykalna, lewicowa partia powstała w 1901 z połączenia środowisk narodnickich (Narodnej Woli - Woli Ludu); czołowymi ideologami wów-
} 
ci bliscy kadetom ${ }^{4}$ i drobne ugrupowania; bolszewicy byli bardzo słabi ${ }^{5}$ i ówcześnie jeszcze niewidoczni. Przewodniczącym Centralnej Rady został obrany uczony i niekwestionowany lider ukraińskiego ruchu narodowego, o poglądach socjalistycznych i federalistycznych, demokrata, Mychajło Hruszewśkyj [Hruszewski] ${ }^{6}$,

czas byli Wiktor Czernow, Borys Sawinkow, Mikolaj Awksientiew, Katarzyna Breszko-Breszkowska; główną siłę rewolucji widzieli w chłopach, toteż dążyli do poprawy ich sytuacji ekonomicznej (uspołecznienie ziemi) oraz politycznej (prawa wyborcze); w końcu 1901 r. powstała Organizacja Bojowa Partii S-R, na czele której stanął Grzegorz Gerszuni, a potem przez pewien czas agent ochrany Jewno Azef; program zakładał walkę rewolucyjną z caratem i utworzenie republiki demokratycznej oraz przekształcenie Rosji w republikę federacyjną; odrzucali dyktaturę proletariatu; stosowali terror indywidualny (liczne udane zamachy, m.in. na ministra praw wewnętrznych W. Plehwego 1904 i wielkiego księcia Sergiusza Aleksandrowicza 1905); od 1905 wśród czołowych przywódców byli Aleksander Kiereński i B. Sawinkow; eserowcy odegrali istotną rolę w rewolucji 1905 r., po czym ich działalność osłabła, po rewolucji lutowej 1917 zaktywizowali się i stali się najliczniejszą partią polityczną Rosji, ale byli wewnętrznie niejednolici, podzieleni na prawicę i lewicę, przy czym po listopadzie $1917 \mathrm{r}$. frakcja lewicowa s-r usamodzielniła się; wchodzili w skład rosyjskiego Rządu Tymczasowego; do sierpnia 1917 r. wspólnie z mienszewikami mieli większość w radach delegatów robotniczych, chłopskich i żołnierskich; w wyborach w listopadzie 1917 r. do Konstytuanty zdobyli ponad 50\% głosów i mandatów; prawica s-r wystąpiła przeciwko bolszewickiemu zamachowi i organizował centra oporu m.in. na Powołżu, Dalekim Wschodzie i Syberii, uczestniczyli w powstaniach chłopskich, także w powstaniu marynarzy Kronsztadu; lewica s-r zaś współpracowała z bolszewikami i do marca 1918 (do traktatu brzeskiego) współtworzyła rząd (Radę Komisarzy Ludowych); w lipcu 1918 podjęli próbę zbrojnego obalenia władzy bolszewików, po czym zostali zlikwidowani przez Czekę; na Ukrainie zaś odrębną Ukraińską Partię Socjalistów-Rewolucjonistów oficjalnie założono w kwietniu 1917, a jednym z jej liderów stał się M. Hruszewski (zob. niżej). Zob. m.in. Leksykon historii świata, red. A. Bartnicki, Warszawa 1998, s. 413; Leksykon historii świata: Rosja, red. W. Sienkiewicz, Warszawa 2001, s. 238-239; B. Bankowicz, M. Bankowicz, A. Dudek, Stownik historii XX wieku, wyd. 2 rozsz., Kraków 1993, s. 120-121, passim.

${ }^{4}$ Kadeci - konstytucyjni demokraci; Partia Konstytucyjno-Demokratyczna, od 1906 r. Partia Wolności Ludu; utworzona w październiku 1905, zwana partią liberałów rosyjskich; skupiała głównie inteligencję i liberalną szlachtę; program przewidywał wprowadzenie w Rosji monarchii konstytucyjnej; po rewolucji lutowej opowiedzieli się za ustrojem republikańskim; mieli w programie dokonanie ograniczonej reformy rolnej; posłowie konstytucyjnych demokratów wchodzili do wszystkich czterech Dum Państwowych (1905-1907); w czasie I wojny głosili hasło walki aż do zwycięstwa; po bolszewickim zamachu stanu opowiedzieli się przeciwko bolszewikom, a ci ogłosili ich wrogami ludu i represjonowali. Leksykon historii świata: Rosja ..., s. 139.

5 W. Serczyk oblicza, że ,w marcu 1917 r. liczba członków SDPRR(b) na Ukrainie [...] była to przysłowiowa kropla w morzu (zaledwie nieco więcej niż 3\%). Gdyby podstawę szacunku rozszerzyć o robotników rolnych i wojsko, procent zorganizowanego proletariatu zmniejszyłby się jeszcze bardziej”. W. Serczyk, Historia Ukrainy, wyd. 4, Wrocław 2009, s. 253.

${ }^{6}$ Mychajło Siergiejewicz Hruszewśkyj [Hruszewski] 1866-1934; wybitny historyk ukraiński; ur. w Chełmie; gimnazjum ukończył w Tyflisie, a studia historyczne na Uniwersytecie w Kijowie, promotorem rozprawy doktorskiej H. był prof. Włodzimierz Antonowicz, Polak z pochodzenia; przez dwadzieścia lat (do 1914) kierował katedrą na Uniwersytecie we Lwowie, a przejściowo także w Petersburgu i Kijowie; działał w Narodowym Towarzystwie im. Tarasa Szewczenki we Lwowie; wspólnie z Iwanem Franko założył i wydawał czasopismo naukowe „Literaturno-Nauko- 
właśnie w wyniku amnestii ogłoszonej przez Rząd Tymczasowy (już 3/16 marca $1917^{7}$ ) zwolniony z przymusowego osiedlenia i znajdujący się w tym momencie w drodze do Kijowa. Postać przewodniczącego - uczonego historyka i publicysty - była znamienna zarówno dla składu osobowego samej Rady, jak też dla klimatu odrodzenia narodowego, budzonego pracami historycznymi Hruszewskiego, postaci o nader barwnym życiorysie i zmiennych losach. Jego zastępcą w funkcji przewodniczącego Centralnej Rady został Dmytro Doroszenko ${ }^{8}$ (nie

wyj Wistnyk", będące do I wojny światowej najważniejszym forum wymiany myśli ukraińskich elit politycznych i kulturalnych; opublikował wiele dzieł z historii narodu ukraińskiego; jego liczne prace historyczne, zwłaszcza 10-tomowa historia Ukrainy do 1658 roku, przyczyniały się do ugruntowania świadomości narodowej Ukraińców, a nawet do ostatecznego upowszechnienia samej nazwy „Ukraina”; w swoich dziełach odrzucał punkt widzenia imperialnej historiografii rosyjskiej, która prowadziła do nieuznawania istnienia narodu ukraińskiego; odrzucał rosyjską koncepcję ciągłości historycznej od Kijowa do Moskwy na rzecz stworzonego przez siebie schematu wykluczającego Rosję, ciągłości: Kijów - Księstwo Halicko-Wołyńskie - państwo kozackie - odrodzenie ukraińskie w XIX w.; był założycielem Ukraińskiego Tow. Naukowego w Kijowie oraz Tow. Ukraińskich Postępowców (1908); stał się jednym z liderów Ukraińskiej Partii Socjalistów-Rewolucjonistów; po wybuchu I wojny światowej internowany wobec powiązań ze Związkiem Wyzwolenia Ukrainy we Lwowie, który opowiadał się za zjednoczeniem ziem ukraińskich jako autonomicznych w ramach monarchii habsburskiej na wzór autonomii Galicji; pod nadzorem policji przymusowo osiedlony najpierw w Symbirsku, później w Kazaniu, Moskwie; w listopadzie 1917 r. poparł ogłoszenie Ukraińskiej Republiki Ludowej, a 29 IV 1918 r. Ukraińska Centralna Rada wybrała go na prezydenta swojego organu wykonawczego (tzw. Małej Rady), co miało znaczenie jedynie symboliczne wobec zamachu stanu dokonanego przez Pawło Skoropadśkiego; wyjechał (1919) do Wiednia, gdzie zabiegał o poparcie międzynarodowe dla URL, ale też kontynuował pracę naukową; pozytywnie odbierał prowadzoną w pierwszej połowie lat dwudziestych politykę radziecką popierania mniejszości narodowych i w związku z tym przyjął (1924) zaproszenie do powrotu na Ukrainę, gdzie przez kilka lat był honorowany i kontynuował działalność naukową, m.in. współpracując z Narodowym Towarzystwem im. Tarasa Szewczenki we Lwowie; w 1930 r. oskarżony o burżuazyjny nacjonalizm i niezgodność jego prac z nauką marksistowską przeniesiony został do Moskwy, co ułatwiło likwidację stworzonej przez niego szkoły historycznej; w 1931 r. aresztowany w związku ze sprawą Ukraińskiego Centrum Narodowego, ale wkrótce zwolniony; zmarł na Kaukazie, gdzie udał się w celach zdrowotnych; jego wizja historii Ukrainy niezależnie od historii Rosji była w ZSRR ostro zwalczana, a ogromny (ok. 1800 prac) dorobek H. przemilczany. T. Stryjek, [w:] Słownik biograficzny Europy Środkowo-Wschodniej, red. W. Roszkowski, J. Kofman, Warszawa 2004, s. 458-460; G. Przebinda, J. Smaga, Kto jest kim w Rosji po 1917 roku, Kraków 2000, s. 106; Wielka Encyklopedia Powszechna PWN [WEP] XI 485; Історія держави і права Украӥни..., t. 2, s. 40; A. Olechno, Instytucja prezydenta na tle początków państwowości ukraińskiej, „Miscellanea Historico-Iuridica” 8 (2009), s. 116-119, passim; Leksykon historii świata, red. A. Bartnicki..., s. 165; Я. Малик, Михайло Грушевський: Незбитий илях. Нариси життя та діяльності, Львів 2016, s. 512.

${ }^{7}$ История отечественного государства и права..., ч. 1, s. 460.

${ }^{8}$ Dmytro Doroszenko (1882-1951 Monachium), ukraiński historyk i polityk, pochodził z rodziny kozackiej z Czernihowszczyzny wywodzącej się od hetmana Petra Doroszenki (XVII w.); gimnazjum w Wilnie, studia historyczne rozpoczął w Warszawie, kontynuował w Petersburgu i ukończył w Kijowie; od początku aktywny w Ukraińskiej Partii Rewolucyjnej oraz Ukraińskiej Partii Rady- 
mylić z Wołodymyrem Doroszenko9), a w składzie Rady znaleźli się m.in. Sergiusz Jefremow ${ }^{10}$, jedna $\mathrm{z}$ głównych postaci wcześniej Towarzystwa Ukraińskich Postępowców ${ }^{11}$ przekształconego następnie (VI 1917) w Ukraińską Partię Socjalistów Federalistów. Ukraińską Partię Socjalistów-Rewolucjonistów, oficjalnie założoną w kwietniu 1917 r., reprezentowali m.in. W. Hołubowicz ${ }^{12}$, Mykyta

kalnej; później w Towarzystwie Ukraińskich Postępowców, a po jej przekształceniu w Ukraińskiej Partii Socjalistów-Federalistów; publicysta, historyk, nauczyciel; Ukraińska Centralna Rada powołała (VIII 1917) na stanowisko gubernialnego komisarza Czernihowszczyzny; po zamachu stanu Skoropadśkiego przyjął (V 1918) w rządzie hetmana stanowisko ministra sprawa zagranicznych; po upadku Skoropadśkiego przebywał na emigracji w wielu krajach Europy i w Kanadzie, łącząc pracę naukową i dydaktyczną historyka z działalnością głównie charytatywną i umiarkowanie polityczną, m.in. w latach 1931 w Warszawie wykładał na Wydziale Teologii Prawosławnej UW i pracował w Ukraińskim Instytucie Naukowym; do śmierci piastował stanowisko Ukraińskiej Wolnej Akademii Nauk. T. Stryjek, [w:] Słownik biograficzny Europy Środkowo-Wschodniej..., s. 273-274.

${ }^{9}$ Wołodymyr Doroszenko (1879-1963 Filadelfia), ukraiński historyk literatury, działacz społeczny, polityk; w Ukraińskiej Partii Rewolucyjnej, a następnie w Ukraińskiej Socjaldemokratycznej Partii Robotniczej; inwigilowany przez policję carską przeniósł się za granicę - do Lwowa, gdzie w latach 1908-1944 pracował w Naukowym Towarzystwie im. Tarasa Szewczenki; w latach I wojny zasiadał w prezydium Związku Wyzwolenia Ukrainy, który miał w programie oderwanie Ukrainy Naddnieprzańskiej od Rosji i utworzenie Ukrainy jako autonomicznego kraju w ramach monarchii habsburskiej; mieszkał w Niemczech, a następnie w USA; pozostawił bogatą spuściznę z dziedziny historii literatury. T. Stryjek, [w:] Słownik biograficzny Europy Środkowo-Wschodniej..., s. 274-275.

${ }^{10}$ Serhij Jefremow (1876-1939), ukraiński historyk literatury, krytyk literacki, polityk; pochodził z rodziny duchownego, ukończył szkoły duchowne, a następnie prawo na uniwersytecie w Kijowie; współtwórca formacji politycznych wyrastających w środowiskach inteligencji ukraińskiej, o poglądach federalistycznych, a społecznie dość radykalnych (nacjonalizacja przemysłu oraz reforma rolna bez odszkodowań); od założenia (1808) wszedł do Towarzystwa Ukraińskich Postępowców; wszedł (III 1917) do Ukraińskiej Centralnej Rady jako zastępca Hruszewskiego; współzałożyciel (1917) Ukraińskiej Partii Socjalistów Federalistów; wszedł (IV 1917) w skład zarówno tzw. Małej Rady UCR jako wiceprezydent przy Hruszewskim, jak też po jej przekształceniu do Sekretariatu Generalnego UCR; w racji tych funkcji uczestniczył w rozmowach UCR z Rządem Tymczassowym w Piotrogrodzie w sprawie statutu Ukrainy w państwie rosyjskim; po upadku Ukraińskiej Centralnej Rady współpracował z przedstawicielem orientacji niepodległościowej - Dyrektoriatem Symona Petlury; pozostał w USRR oddając się wyłącznie pracy naukowej; aresztowany (1928) w tzw. procesie Związku Wyzwolenia Ukrainy i skazany za przygotowywanie spisku celem obalenia władzy socjalistycznej i budowy Ukrainy burżuazyjnej; odrzucił osobistą ofertę Stalina ułaskawienia za cenę oddania swego pisarstwa na usługi reżimu; skazany najpierw na karę śmierci, zamienioną na 10 lat łagru, zmarł prawdopodobnie w 1937 r. T. Stryjek, [w:] Stownik biograficzny Europy Środkowo-Wschodniej..., s. 509-510; Історія держави і права України ..., t. 2, s. 40.

${ }_{11}$ Towarzystwo Ukraińskich Postępowców, ponadpartyjna organizacja założona w Kijowie w 1908 r. przez M. Hruszewskiego i S. Jefremowa, bliska poglądom Partii Konstytucyjnych Demokratów, żądająca przyznania Ukrainie autonomii.

12 Wsewołod Hołubowicz (1885-1939), syn duchownego, inżynier; członek Ukraińskiej Partii Rewolucyjnej, później Ukraińskiej Partii Socjalistów-Rewolucjonistów; wybrany do odeskiej dumy miejskiej, do rosyjskiej konstytuanty; członek Ukraińskiej Centralnej Rady, objął resorty gospodarcze w Sekretariacie Generalnym Centralnej Rady, czyli w rządzie UCR; podejmował starania zmie- 
Szapował ${ }^{13}$ (nie mylić z Mykołą Szapowałem ${ }^{14}$ ). Obecna była i stopniowo zyskiwała na znaczeniu zbliżona do mienszewików Ukraińska Socjaldemokratyczna Partia Robotnicza z jej liderem Wołodymyrem Wynnyczenko ${ }^{15}$ i Symonem Pet-

rzające do zaopatrzenia wojennego wojsk Ukraińskiej Republiki Ludowej; przewodniczył delegacji ukraińskiej na separatystyczne rokowania pokojowe w Brześciu (XII 1917-III 1918); po dymisji rządu Wynnyczenki został (18 I 1918) premierem URL; w wyniki ofensywy sił zbrojnych radzieckich rząd H. usunął się i przebywał na Wołyniu, a do Kijowa powrócił z wojskami niemieckimi, ale stał się marionetką w rękach niemieckich i został obalony (29 IV 1918) przez Skoropadśkiego przy wsparciu niemieckim; H. został aresztowany i przebywał w więzienia aż do obalenia Skoropadśkiego przez Dyrektoriat URL (XII 1918); podjął współpracę z nowym rządem; w drugiej połowie 1919 r. z Kamieńca Podolskiego kierował walką wojsk URL przeciwko bolszewikom oraz białej Armii Ochotniczej gen. Antona Denikina; po raz pierwszy aresztowany przez bolszewików w sierpniu 1920 r. i skazany na 5 lat łagru, zwolniony po kilkunastu miesiącach na mocy amnestii; pracował w administracji gospodarczej USRR; ponownie aresztowany w 1931 r. pod zarzutem udziału w antysocjalistycznym spisku pod nazwą Ukraińskiego Centrum Narodowego, na torturach przyznał się do rzekomej winy; zmarł w lagrze lub więzieniu. T. Stryjek, [w:] Słownik biograficzny Europy Środkowo-Wschodniej..., s. 440-441.

${ }_{13}$ Mykyta Szapował (1882-1932), ukraiński polityk, socjolog i poeta; pochodził z rodziny chłopskiej; członek (1901) Ukraińskiej Partii Rewolucyjnej; wydalony ze szkoły oficerskiej i z armii za działalność rewolucyjną; więziony 8 miesięcy w Cytadeli Warszawskiej; studiował w Charkowie, ale studiów nie ukończył; współredagował czasopismo rewolucyjne; 1917 wspólnie z Hruszewskim organizował Ukraińską Partię Socjalistów-Rewolucjonistów i reprezentował ją w Ukraińskiej Centralnej Radzie i tzw. Małej Radzie, później został członkiem Sekretariatu Generalnego UCR (czyli rządu ukraińskiego); w opozycji do Skoropadśkiego uczestniczył w obaleniu jego rządów; jako minister rolnictwa w rządzie Czechiwśkiego przygotowywał dekrety o reformie rolnej mające być realizacją programu rolnego eserowców; po zwycięstwie bolszewików udał się na emigrację, osiadł do końca życia w Pradze, gdzie prowadził pracę naukową i łączył ją z polityczną. T. Stryjek, [w:] Stownik biograficzny Europy Środkowo-Wschodniej..., s.1241-1242.

${ }^{14}$ Mykoła Szapował, brat Mykyty, generał armii Ukraińskiej Republiki Ludowej, a następnie lider ukraińskiej emigracji we Francji.

15 Wołodymyr Wynnyczenko (1880-1951 w Mougins); ukraiński pisarz i polityk; członek (1901) Ukraińskiej Partii Rewolucyjnej, która w 1905 przekształciła się w Ukraińską Partię Socjaldemokratyczną; 1907-1914 na emigracji głównie we Francji napisał wiele utworów przedstawiających rewolucję 1905; po powrocie aktywnie działał w narodowym skrzydle ruchu socjaldemokratów; był (IV 1917) jednym z inicjatorów powołania Ukraińskiej Centralnej Rady i został jej wiceprezydentem; reprezentował UCR w rozmowach z piotrogrodzkim Rządem Tymczasowym w sprawie autonomii Ukrainy i uznania jej tymczasowych władz; po odrzuceniu tych postulatów napisał I Uniwersał i objął kierowanie Sekretariatem Generalnym UCR (rządem); sygnował także III Uniwersał, proklamujący niezależną Ukraińską Republikę Ludową; W. szukał porozumienia z bolszewikami; pośredniczył w rozmowach między UCR a Skoropadśkym; stanął (14 XI 1918) na czele Dyrektoriatu; wyjechał (II 1919) na emigrację, ale wkrótce przyjął koncepcję współpracy z bolszewikami i wrócił na Ukrainę radziecką, przyjął funkcję wiceprzewodniczącego Rady Komisarzy Ludowych (rządu) USRR; rozczarowany wyjechał ponownie; we Lwowie i w Pradze wydawał pamiętniki, pisma polityczne oraz utwory literackie wznawiane po 1991. W Roszkowski, [w:] Stownik biograficzny Europy Środkowo-Wschodniej..., s. 1399-1400; Історія держави і права України..., t. 2 , s. 40 i n. 
lurą, ci dwaj w latach 1900-1905 należeli do Ukraińskiej Partii Rewolucyjnej ${ }^{16}$. Zauważyć należy, że Ukraińska SDPR obrała kurs całkowicie sprzeczny z kierunkiem istniejącej również w Kijowie jej odpowiedniczki rosyjskiej SDPRR(b) ${ }^{17}$, która od razu Centralną Radę z jej programem narodowym uznała za instytucję burżuazyjno-nacjonalistyczną.

Centralna Rada, zajmując zrazu względem Rządu Tymczasowego w Piotrogrodzie stanowisko ugodowe, a nawet rząd wspierające, stopniowo coraz silniej artykułowała żądania przyznania Ukrainie autonomii w ramach demokratycznej republiki rosyjskiej. Zakres terytorialny tej autonomii nie był sprecyzowany i wyrażał się żądaniem w odniesieniu do wszystkich terytoriów, gdzie ludność mówi językiem ukraińskim, włącznie z Kubaniem ${ }^{18}$. W publicznych dyskusjach

${ }_{16}$ Ukraińska Partia Rewolucyjna powstała w 1900 r. Jej założycielem było stowarzyszenie studentów Charkowa. Jest to pierwsza nowoczesna partia polityczna na Ukrainie Naddnieprzańskiej. Program dla partii napisał adwokat Mykoła Michnowski; pod tytułem „Niepodległa Ukraina” pojawił się on drukiem we Lwowie. Partia głosiła, że końcowym celem jej działalności będzie niepodległe państwo ukraińskie złożone ze wszystkich ziem zamieszkanych przez naród ukraiński. Dla jego osiągnięcia najpierw należało przywrócić Ukrainie autonomię w składzie Rosji, według umowy z 1654 r. hetmana Chmielnickiego z carem moskiewskim Aleksiejem Michajłowiczem. Partia istniała do roku 1905.

${ }^{17}$ Socjaldemokratyczna Partia Robotnicza Rosji - założona w 1898 r. na zjeździe w Mińsku. Szczególnie ważną rolę w jej skonsolidowaniu i opracowaniu programu miała założona w $1900 \mathrm{r}$. przez Lenina gazeta „Iskra”. Drugi Zjazd SDPRR (Bruksela-Londyn 1903) w toku ostrych dyskusji uchwalił program partii, ale owe dyskusje doprowadziły do powstania dwóch ugrupowań: bolszewików i mienszewików, których ostateczne zerwanie nastąpiło w 1912 r., kiedy to na konferencji w Pradze wybrano wyłącznie bolszewicki Komitet Centralny z Leninem na czele. Bolszewicy występowali odtąd jako SDPRR (bolszewików). Partia była oparta na silnej centralizacji i ostrej dyscyplinie wewnętrznej. W programie bolszewików znalazło się m.in. przekształcenie przyszłej rewolucji burżuazyjnej w Rosji w rewolucję socjalistyczną, co jako pogląd niemarksistowski odrzucane było przez większość teoretyków europejskiej socjaldemokracji wobec znacznego zacofania ekonomicznego i społecznego Rosji. W marcu 1918 r. na III Zjeździe nastąpiła zmiana nazwy partii na Rosyjską Komunistyczną Partię (bolszewików). Na X zjeździe RKP(b) w marcu 1921 r. wprowadzony został zakaz tworzenia frakcji w partii, co stało się wielkim ułatwieniem dalszej ewolucji w kierunku tzw. stalinizmu. Frakcje mogły być przynajmniej skromną namiastką wielopartyjności w państwie. Na posiedzeniu KC w kwietniu 1922 r. ustanowiono stanowisko sekretarza generalnego, które z rekomendacji Lenina powierzono Stalinowi. Nie istniało stanowisko przewodniczącego partii; niekwestionowanym liderem był Lenin. W grudniu 1925 r. nastąpiła zmiana nazwy na Wszechzwiązkową Komunistyczną Partię (bolszewików). W październiku 1952 r. zmieniono nazwę na Komunistyczną Partię Związku Radzieckiego, a w miejsce sekretarza generalnego wprowadzono I sekretarza, zaś od 1966 r. znowu sekretarza generalnego. Wówczas też w miejsce Biura Politycznego wprowadzono Prezydium KC. W Prezydium - na wniosek Stalina - wyodrębniono jeszcze Biuro Prezydium. W ścisłym Biurze Stalin wyodrębnił jeszcze „piątkę” głównych członków Prezydium (Stalin, Malenkow, Beria, Bułganin, Chruszczow). Komunistyczna Partia Związku Radzieckiego została w Rosji zdelegalizowana przez Jelcyna bezpośrednio po sierpniowym „puczu Janajewa" (24 VIII 1991 r.). Do końca 1991 r. pozostałe b. republiki zdelegalizowały KPZR.

${ }_{18}$ История отечественного государства и права..., ч. 1, s. 456. 
prasowych i na wiecach pojawiały się żądania dalej idące: sfederalizowania Rosji i Ukrainy, a nawet pełnej suwerenności. W tej sytuacji nadchodzący rozwój wydarzeń musiał prowadzić do konfliktu między Piotrogrodem a Kijowem. Zabiegając o uzyskanie szerszego poparcia społeczności ukraińskiej, Centralna Rada szybko (kwiecień 1917 r.) doprowadziła do zwołania w Kijowie I Ukraińskiego Zjazdu Narodowego z udziałem około tysiąca delegatów reprezentujących rozmaite kręgi społeczne i organizacje, także wojskowe. Na Zjeździe Centralna Rada uzyskała potwierdzenie swojej roli jako reprezentanta społeczeństwa ukraińskiego, ale wówczas nie chodziło jej jeszcze o przekształcenie w instytucję terytorialną reprezentującej ogół ludności guberni ukraińskich. Formalnie nie mogła więc na razie pretendować do roli ośrodka władz krajowych. Zjazd faktycznie skonstruował nową Centralną Radę. Najpierw wybrano Wielką Radę w składzie 118 osób, która zbierała się na sesje plenarne nie rzadziej niż raz w miesiącu i podejmowała najważniejsze uchwały. Natomiast dla zarządzania sprawami bieżącymi powołano dwudziestoosobową Małą Radę, która pracowała permanentnie ${ }^{19}$. Ta ostatnia jako organ wykonawczy składała się m.in. z prezydenta ${ }^{20}$ (Hruszewski) oraz dwóch wiceprezydentów (Jefremow, Wynnyczenko). Małą Radę (potocznie zwaną też komitetem) skonstruowano tak, aby weszli do niej reprezentanci wszystkich najważniejszych ukraińskich stronnictw politycznych i organizacji społecznych. W ramach tej instytucji powołano komisje: organizacyjną, wojskową, edukacyjną, prawniczą, skarbową etc. Centralna Rada powstała jako instytucja narodowa, ale wyraźnie dążyła do przekształcenia się w organ administracji terytorialnej.

Bardzo aktywne stało się środowisko wojskowe. Jak wiadomo, I wojna światowa ogarnęła większą część ziem ukraińskich. Właśnie tu rozciągał się najdłuższy front armii rosyjskiej - południowo-zachodni $(615 \mathrm{~km})$. Warto pamiętać, że na terenie Ukrainy znajdowała się baza floty czarnomorskiej. W formacjach wojskowych tego frontu liczono powyżej $3 \mathrm{mln} 839$ tys. osób ${ }^{21}$. Ogółem na początku 1917 r. armia rosyjska liczyła 6798 tys. osób służby czynnej i 2260 tys. w formacjach zapasowych. Ukraińcy stanowili najliczniejszą jej część spośród narodowości nierosyjskich: ich liczba wynosiła około 3,5 mln osób, co stanowiło prawie $40 \%$ składu osobowego wojska cesarstwa rosyjskiego ${ }^{22}$. Rząd carski, oba-

19 М. Грушевський, Як зложилася Центральна Рада, [w:] Хто такі украӥнці $і$ чого вони хочуть?, Київ 1991, s. 8; Довідник з історії України. За ред. І. Підкови, Р. Шуста, Київ 2001, s. 953.

${ }^{20}$ Niuanse prawne w związku z dylematem czy prezydent UCR był głową państwa (prezydentem państwa), czy przewodniczącym organu przedstawicielskiego fachowo roztrząsa A. Olechno, Instytucja Prezydenta w systemie konstytucyjnych organów Ukrainy (1996-2005), Torun 2009, s. 11-14; idem, Instytucja prezydenta na tle początków państwowości..., s. $110 \mathrm{i} \mathrm{n.}$

21 В. Голубко, Армія Украӥнської Народної республіки 1917-1918. Утворення і боротьба за державу, Львів 1997, s. 24.

22 Россия в мировой войне 1914-1918 (в цииррах), Москва 1925, s. 4. 
wiając się ruchów separatystycznych, dążył do jak największego przemieszania w wojsku różnych narodowości. Z reguły każda jednostka wojskowa winna była mieć w swoim składzie nie mniej niż 50\% Rosjan. W latach I wojny światowej na Ukrainie istniały dwa okręgi wojskowe: kijowski i odeski. Część terenów ukraińskich, jak doniecki rejon przemysłowy i kilkanaście powiatów guberni charkowskiej, włączono do moskiewskiego okręgu wojskowego. Podobnymi przedsięwzięciami rząd rosyjski pragnął nie dopuścić do koncentrowania Ukraińców w rozlokowanych na Ukrainie jednostkach. Działania wojenne utrudniły władzom carskim przetransportowanie większości żołnierzy ukraińskich poza granice Ukrainy, więc poczynając od 1916 r., ich odsetek wśród zgromadzonych tam wojsk ciągle wzrastał. Potwierdzają to dane dotyczące składu narodowościowego wojsk południowo-zachodniego i rumuńskiego frontów przecinających Ukrainę z północy na południe: w pierwszym kontyngent ukraiński liczył $1 / 3$, a drugim $1 / 4$ część składu osobowego ${ }^{23}$. Flota czarnomorska w $65 \%$ była złożona z marynarzy Ukraińców ${ }^{24}$.

Powstanie Centralnej Rady, nieoczekiwanie dla jej przywódców, największy oddźwięk znalazło wśród żołnierzy narodowości ukraińskiej. Jak stwierdzał przewodniczący Centralnej Rady M. Hruszewski, ,ruch w wojsku stał się w ciągu następnych miesięcy najmocniejszą siłą dynamizującą dla ruchu ukraińskiego", a najbardziej nieoczekiwane było to, że przejawiał się on w pragnieniu tworzenia jednostek ukraińskich i wyodrębnienia ich w osobne wojsko ${ }^{25}$. W tym czasie M. Hruszewski wyraźnie opowiadał się za przekształceniem Rosji w federacyjną republikę, więc uważał za normalne, że nie Ukraina, a organy federalne będą odpowiedzialne za zarządzanie siłami zbrojnymi republiki ${ }^{26}$. Ukraiński ruch wojskowy rozwijał się dynamicznie. Należy zwrócić uwagę, że podłożem tego były przyczyny socjalne: nadzieja, że rewolucja rozwiąże problem agrarny, więc w przekonaniu żołnierzy ukraińskich trzeba śpieszyć się do domu, aby zdążyć na czas spodziewanej reformy rolnej. Najlepszym sposobem osiągnięcia tego celu było przeniesienie służby na Ukrainę. Pobudki narodowe odgrywały pewną rolę, ale na razie nie były decydujące. Już w marcu 1917 r. dawną armię carską ogarnęła fala ukraińskiego ruchu, która znalazła przejaw w żądaniu żołnierzy ukraińskich otrzymania zezwolenia na wyodrębnienie oddzielnych ukraińskich jed-

${ }^{23}$ А.Г. Ткачук, Революиионное движение в армиях Юго-Западного и Румынского фронтов накануне Великого Октября. Автореф. дис. д.и.н., Львов 1968, s. 17.

24 Д.А. Гаркавенко, Социальный состав матросов русского флота в эпоху империализма, „История СССР” (1968), № 5, s. 55.

${ }_{25}$ М. Грушевський, Новий період історії Украйни за роки від 1914 до 1919, Київ 1992 , s. 16.

${ }_{26}$ М. Грушевський, Якої автономії ми хочемо, [w:] idem, Хто такі українці і чого вони хочуть?, Київ 1991, s. 133. 
nostek wojskowych. Ruch ten określany jest jako ukrainizacja rosyjskiej armii carskiej. Charakterystycznie, że większość liderów Centralnej Rady obojętnie, a nawet niechętnie była ustosunkowana do idei wykorzystania go w celu tworzenia narodowych sił zbrojnych. Był to efekt federalistycznej koncepcji państwowotwórczej ówczesnego kierownictwa ukraińskiego. Brak inicjatywy Centralnej Rady w przedmiocie wojskowości wykorzystały niepodległościowe stronnictwa polityczne, będące w opozycji do przywództwa Centralnej Rady. Właśnie one grupowały zwolenników tworzenia narodowych sił zbrojnych. Z ich inicjatywy w marcu 1917 r. w Kijowie powstały dwie organizacji wojskowe, które zdecydowanie opowiedziały się za wykorzystaniem ukrainizacji dla tworzenia regularnego wojska ukraińskiego: Komitet Organizacyjny dla formowania wojska ukraińskiego i Klub Wojskowy imienia hetmana Połubotki. Jednak plany stronnictw niepodległościowych napotkały na szereg przeszkód. Najbardziej dotkliwy był brak doświadczonej wyższej kadry oficerskiej. Natomiast Ukraińcy stanowili poważną część młodszej kadry oficerskiej. Miało to swoje zalety, ponieważ ułatwiło działalność propagandową wśród szeregowców.

Ukrainizacja armii rosyjskiej zaczynała się samorzutnie wbrew rosyjskim władzom wojskowym i cywilnym. Powstał przeto problem ustanowienia naczelnego organu wojskowego, który podjąłby pracę organizacyjną. Wbrew oczekiwaniom pomysł nie uzyskał akceptacji czołowych działaczy Centralnej Rady, którzy byli federalistami i antymilitarystami z przekonania. Na przykład zastępca przewodniczącego Centralnej Rady, a później premier rządu Ukraińskiej Republiki Ludowej Wołodymyr Wynnyczenko wywodził, że „Ukraina nie ma po co wojować, ponieważ nikogo niewolić nie chce. Obecnie Ukraina potrzebuje zakończyć wojnę i urządzić wspólnie z rosyjskimi klasami pracującymi nowe życie we wspólnym państwie - Rosji”27. Pod naciskiem żołnierzy ukraińskich Centralna Rada zwołała 18-21 maja 1917 r. pierwszy wszechukraiński zjazd wojskowy, który nadał ruchowi ukrainizacji kształty organizacyjne. Zjazd uznał Centralną Radę za jedyną legalną władzę na Ukrainie oraz powołał Ukraiński Wojskowy Komitet Generalny z Symonem Petlurą na czele ${ }^{28}$. Generalny Komitet Wojskowy miał pełnić rolę zalążka sztabu narodowych sił zbrojnych. S. Petlura w swym przemówieniu na zjeździe wyznaczył pierwszorzędny cel Komitetu: „wydrzeć ukraińskich żołnierzy z rąk rosyjskiego dowództwa i skoncentrować ich na jednym froncie" 29 .

Żądania wojskowych były równie kategoryczne, co i wszechstronne. Na plan pierwszy wysuwały się oczekiwania dotyczące formowania narodowych jednostek

27 „Вісти з Української Центральної Ради” 1917, Nr. 3.

${ }^{28}$ W. Serczyk, Historia Ukrainy..., s. 254; R. Pipes, Czerwone imperium..., s. 58-59; zob. też История отечественного государства и права..., ч. 1, s. 456.

29 А. Кмета, Пам'яти Незабутнього, „Табор” (1927), сz. 5, s.15. 
wojskowych w ramach armii rosyjskiej, a za tym szły czyny w wojsku, gdzie żołnierze ukraińscy, nie czekając na decyzje i zgody, tworzyli swoje oddziały wojskowe. Dla Ukrainy zaś domagano się autonomii w Rosji i natychmiastowego powołania w Rządzie Tymczasowym specjalnego ministra do spraw Ukrainy (wzór galicyjski?). Zgłoszono też postulat uczestniczenia reprezentacji ukraińskiej w przyszłej konferencji pokojowej. Żądania złożono zarówno Rządowi Tymczasowemu, jak i Komitetowi Wykonawczemu Piotrogrodzkiej Rady; dwuwładza widoczna była z Kijowa, chociaż na terytorium Ukrainy nie miała takiego znaczenia, jak w Rosji. Analogiczne żądania sformułował obradujący wkrótce (maj - czerwiec 1917 r.) I Ogólnoukraiński Zjazd Chłopski, ale ten zjazd w sprawach socjalnych poszedł bardzo daleko, formułując oczekiwanie nacjonalizacji ziemi, zniesienie jej prywatnej własności i oddanie do dyspozycji komitetów gminnych ${ }^{30}$. Piotrogrodzki Rząd Tymczasowy, rewolucyjny ale legalistyczny, nie mógł zaakceptować większości tak daleko idących żądań i oczekiwań, gdyż nie czuł się do tego upoważniony. W myśl umowy z Radą Piotrogrodzką co do zakresu swoich kompetencji trafnie rozumiał, że te sprawy musi zostawić przyszłej konstytuancie. Żądanie autonomii dla Ukrainy zostało więc przez Rząd Tymczasowy odrzucone ${ }^{31}$. Natomiast UCR sama proklamowała I Uniwersałem (10/23 czerwca 1917 r.) autonomię Ukrainy i powołała 28 czerwca Sekretariat Generalny, będący w istocie rządem Ukrainy ${ }^{32}$. W swoim składzie miał odpowiednie resorty (sekretariaty), ogółem osiem: finansów, spraw międzynarodowych, rolnych, sprawiedliwości, oświaty, aprowizacji, wojskowych oraz „pisarza” generalnego. Jako Sekretarz (minister) Spraw Wojskowych wszedł do niego Petlura ${ }^{33}$.

${ }^{30}$ W. Serczyk, Historia Ukrainy ..., s. 254.

31 История отечественного государства и права..., ч. 1, s. 456.

${ }_{32}$ Історія держави і права Украӥни..., t. 2 , s. 42 і n.

33 Symon Petlura: ur. 1879 w Połtawie, zamordowany 25 V 1926 w Paryżu; polityk, wojskowy, publicysta; pochodził z rodziny drobnomieszczańskiej o tradycjach kozackich i silnych związkach z cerkwią; ukończył szkołę przycerkiewną, natomiast z seminarium duchownego został usunięty (1901) na ostatnim roku za przynależność do nielegalnej ukraińskiej organizacji; od 1900 działał w Ukr. Partii Rewolucyjnej (redagował organ prasowy partii) i potem w jej następczyni Ukr. Socjaldemokr. Partii Robotniczej; w partii reprezentował grupę opowiadającą się za autonomią Ukrainy w federacji rosyjskiej; 1903 aresztowany, zwolniony 1904 za kaucją wniesioną przez ojca, 1905 objęty amnestią; wyjechał najpierw do Kijowa, a potem do Lwowa; od 1908 w Tow. Ukr. Postępowców; 1906-1917 redagował liczne pisma partyjne i narodowe; 1916-III 1917 działał w organizacji pomocy rannym i ludności cywilnej na froncie zachodnim; po utworzeniu III 1917 w Kijowie Ukraińskiej Centralnej Rady [UCR] traktowanej przez Ukraińców jako narodowy parlament, P. wziął udział w I Ogólnoukraińskim Zjeździe Wojskowym, na którym powołano (V 1917) Ukraiński Wojskowy Komitet Generalny, a na jego czele stanął P.; po utworzeniu (VI 1917) Sekretariatu Generalnego UCR, będącego w istocie rządem ukr., P. wszedł w jego skład jako Sekretarz Spraw Wojskowych, a jako cel postawił sobie stworzenie samodzielnej ukraińskiej siły zbrojnej, a to z kolei wywołało obawy rosyjskiego Rządu Tymczasowego i niektórych ugodowo nastawionych członków UCR; P. kierował obradami (VI 1917) II Ogólnoukr. Zjazdu 
Na początku swej pracy część polityków ukraińskich uważała, że Sekretariat Generalny jest organem, który ma przygotowywać ustanowienie autonomii

Wojskowego, na którym zdecydowano o tworzeniu ukr. sił zbrojnych; po przejęciu władzy w Piotrogrodzie przez bolszewików P. opowiedział się za pełną niepodległością Ukrainy i orientacją profrancuską, wbrew UCR, która wybrała orientację proniemiecką i proklamowała (20 XI 1917 tzw. III Uniwersał) powstanie Ukraińskiej Republiki Ludowej jako części federacyjnej Republiki Rosyjskiej, a wkrótce (I 1918) wobec zagrożenia bolszewickiego pełną niepodległość Ukrainy; P. zorganizował zalążek armii narodowej i były to główne siły, które stłumiły (II 1918) bolszewickie powstanie w Kijowie; I 1918 wobec konfliktu z przewodniczącym UCR W. Wynnyczenką P. został usunięty ze stanowiska ministra w rządzie - Sekretarza Spraw Wojskowych, ale faktycznie nadal dowodził własnymi oddziałami wojskowymi; po przewrocie Skoropadśkiego (29 IV 1918) aresztowany (VII-XI 1918); po zakończeniu działań zbrojnych w I wojnie światowej oraz w momencie anulowania przez bolszewików traktatu brzeskiego ukonstytuował się (13 XI 1918) Dyrektoriat celem obalenia rządów niemieckich i Skoropadśkiego na czele z W. Wynnyczenką i P. jako Naczelnym Atamanem Wojsk URL; P. podporządkował sobie zdemoralizowane i zanarchizowane rozmaite ukr. jednostki zbrojne, a zwłaszcza Galicyjskich Strzelców Siczowych, i dokładnie w miesiąc po utworzeniu Dyrektoriatu samodzielnie wkroczył do Kijowa obalając Skoropadśkiego i rządy niemieckie; ujęcie wojska w karby i zaprowadzenie dyscypliny wśród mas żołnierzy URL, bolszewickich, denikinowskich, Machny, mimo stanowczych środków stosowanych przez P. było niemal niemożliwe; m.in. przez kraj przechodziła fala pogromów antysemickich dokonywanych niekiedy w wynaturzony barbarzyński sposób, których dopuszczały się także regularne oddziały wojskowe ukraińskie; szerzyła się dezercja; próby pozyskania Ententy (Ukraina stała się głównie francuską strefą wpływów) napotykały na opory, gdyż władze URL uważane były za zbyt radykalne (zwłaszcza gotów do rozmów z bolszewikami W. Wynnyczenko oraz P.), jak też obciążano je odpowiedzialnością za pogromy żydowskie, a nadto Ententa na pocz. 1919 popierała Denikina; rozmowy w Moskwie nie dały efektów i jeszcze w XII 1918 Rosja dużymi siłami Armii Czerwonej najechała Ukrainę, bolszewicy zdobyli Charków i ogłosili (6 I 1919) zmianę nazwy państwa na: Ukraińska Socjalistyczna Republika Radziecka, zaś 29 I 1919 bolszewicki Tymczasowy Rząd Robotniczo-Chłopski przekształcony został w Radę Komisarzy Ludowych USRR; przewodniczącym wyznaczono komunistę bułgarskiego pochodzenia Chrystiana Rakowskiego; 16 I 1919 Dyrektoriat URL wypowiedział Rosji bolszewickiej wojnę; 11 II 1919 P. zastąpił W. Wynnyczenkę na stanowisku przewodniczącego Dyrektoriatu; rósł chaos, anarchia i okrutne pogromy Żydów, nastąpił rozkład państwa ukraińskiego; P. jako Naczelny Ataman osobiście dowodził armią ukraińską przez cały rok 1919 walcząc z Rosjanami tak białymi (Denikin), jak i czerwonymi; formalne zjednoczenie (sfederowanie) URL i Zachodnioukraińskiej Republiki Ludowej [ZURL] wywołało dodatkowo rozbieżności między politykami obu państw; po zajęciu Kijowa (II 1919) przez bolszewików P. podjął rozmowy z tworzącym się państwem polskim, ale uznanie URL i wojskowa pomoc polska mogły mieć miejsce tylko w zamian za uznanie polskich pretensji do Galicji Wsch. oraz zach. Wołynia; P. starał się przekonać Ukraińców z Galicji do kompromisu i rozejmu w oparciu o tzw. linię Barthélemego w Galicji wsch., zaproponowaną przez przedstawicieli Ententy, co pozwoliłoby przesunąć Ukraińską Armię Galicyjską na front przeciwbolszewicki; propozycje P. nie zostały przyjęte przez Galicjan; na Wołyniu doszło do puczu i próby aresztowania P.; pucz zlikwidowano i Dyrektoriat formalnie znacznie wzmocnił pozycję Atamana P. i mianował (9 V 1919) go Prezesem Dyrektoriatu, co odpowiadało instytucji prezydenta państwa; związek URL i ZURL upadł; VIII 1919 Denikin zajął Kijów, bolszewicy trzymali Charków, ZURL poniosła klęskę w wojnie z Polską; P. próbował jeszcze połączyć siły URL i galicyjskie w „trójkącie śmierci” w rejonie Kamieńca Podolskiego, ale armie straciły ok. 70\% 
Ukrainy, zaś inni skłonni byli go uważać za rząd autonomiczny. Stronnictwa nieukraińskie zajęły wobec niego postawę negatywną, uważając go za reprezentację narodową, a nie terytorialną.

stanu osobowego z powodu tyfusu; Ukraińska Armia Galicyjska zdradziła P. i w połowie XI 1919 przyłączyła się do Armii Ochotniczej Denikina, a po klęsce Denikina przeszła do Armii Czerwonej; to był koniec marzeń o państwie ukraińskim; członkowie Dyrektoriatu udając się na emigrację przekazali pełnię swojej władzy na ręce P., który miał pełnić zadania prezydenta-dyktatora stojącego ponad Radą Ministrów; kiedy na pocz. XII 1919 bolszewicy zajmowali Kijów, wówczas Dyrektoriat URL wydał (2 XII 1919) jednostronną deklarację w sprawie umowy z Polską i zrzekł się na rzecz Polski Galicji Wsch. i pn.-zach. Wołynia; P. z najbliższymi współpracownikami przekroczył linię frontu na stronę polską; w nocy 9/10 XII 1919 doszło do spotkania P. z Piłsudskim; Polska wyraziła zgodę na tworzenie na jej terytorium wojska ukraińskiego i zwolniła jeńców oraz internowanych; 21/22 IV 1920 podpisano w Belwederze sojusz wojskowo-polityczny dot. wspólnej walki z bolszewizmem, Polska uznała Dyrektoriat za najwyższą władzę Ukrainy, strona ukraińska ponownie zrzekła się na rzecz Polski Galicji Wsch. i zach. Wołynia; 25 IV 1920 połączone siły Polski (300 tys.) i URL (4 tys.) uderzyły na bolszewików w celu restytucji państwa ukraińskiego; 7 V 1920 wkroczyły do Kijowa; naród nie poparł P. dając posłuch propagandzie bolszewickiej, ale IV 1920 Ukr. Armia Galicyjska przeszła na stronę P. i polską, by w VII 1920 znowu zdradzić i zdezerterować na stronę Armii Czerwonej, natomiast wojska P. dochowały wierności sojuszowi z Polską; po zawarciu pol.-bol. rozejmu (12 X 1920) na etapie negocjacji pokojowych Polska nie była w stanie obronić interesów ukr.; P. jeszcze desperackim atakiem XI 1920 próbował wywołać na Ukrainie powstanie antybolszewickie, ale poniósł klęskę; żołnierze P., którzy przeszli Zbrucz zostali w Polsce internowani, zaś P. Polska udzieliła azylu politycznego i skromnej pomocy materialnej dla URL; P. wraz z rządem ukr. podtrzymywali działalność ukr. sił antybolsz., rezydując w Tarnowie, potem w Warszawie, w wyniku nacisków sowieckich na Polskę P. 1923 przeniósł się kolejno do Budapesztu, Wiednia, Genewy, wreszcie 1924 do Paryża; wydawał pismo „Tryzub”, nadzorował działalność rządu ukr. na wychodźstwie, podejmował wysiłki w kierunku integracji emigracji ukr.; 25 V 1926 został zamordowany przez żydowskiego emigranta z Besarabii, który na procesie tłumaczył swój czyn zemstą za pogromy dziesiątek tysięcy Żydów na Ukrainie, za co odpowiedzialnością obciążał P.; w wyniku atmosfery wykreowanej przez francuskie media sąd zabójcę uniewinnił uznając jego racje moralne; mimo domysłów, nigdy nie wykazano związku zabójcy ze służbami specjalnymi radzieckimi, ale jest to w najwyższym stopniu prawdopodobne, znamienne że wzmianka Pawła Sudopłatowa o śmierci P. jest kłamliwa; na pogrzebie P. marszałka Józefa Piłsudskiego reprezentował płk Franciszek Kleeberg; pochowany został na cmentarzu Montparnasse; po śmierci ustanowiono krzyż im. Symona Petlury oraz stworzono w Paryżu bibliotekę jego imienia, którą zniszczyli Niemcy w czasie II wojny; pośmiertnie wydano jego mowy, listy, dokumenty; jego życie było obrazem walki o niepodlergłą Ukrainę. C. Partacz, [w:] Encyklopedii „Białych Plam” [EBP] XIV 107-110; T. Stryjek, [w:] Słownik biograficzny Europy Środkowo-Wschodniej..., s. 968-970; В. Голубко, Концепиія Української держави у баченні Симона Петлюри. Вісник Прикарпатського університету. Історія. - Вип.23-24.(До 20-ліття утворення кафедри історії слов'ян і 80-річчя професора Петра Федорчака), Івано-Франківськ 2013, s. 92-96; G. Przebinda, J. Smaga, Kto jest kim w Rosji..., s. 217; WEP XX 513; A. Dudek, [w:] Stownik historii XX wieku ..., s. 313-314; R. Pipes, Czerwone imperium..., passim; Історія держави і права України..., s. 40, 53, 131; A. Serednicki, Symon Petlura - życie i działalność, „Mazowieckie Studia Humanistyczne” (1997), nr 1, s. 81-100; P. Sudopłatow, Wspomnienia niewygodnego świadka, tłum. J. Markowski, Warszawa 1999, s. 41. 


\section{NA FRONCIE I ŚWIATOWEJ (DO LIPCA 1917 ROKU)}

Należy pamiętać, że nad wszystkimi wydarzeniami w Rosji i na Ukrainie wisiała stale sprawa toczącej się wojny, a jej przebieg wszak był dla Rosji w najwyższym stopniu niepomyślny, wręcz dramatyczny i w znacznym stopniu determinował wydarzenia wewnętrzne. Właśnie wówczas (maj - czerwiec 1917 r.) Rząd Tymczasowy przygotowywał wielką ofensywę uzgodnioną z aliantami. Nie może też dziwić, że minister wojny, Aleksander Kiereński ${ }^{34}$, zakazał odbycia drugiego zjazdu wojskowego.

Już koniec pierwszego roku wojny światowej nie był satysfakcjonujący dla żadnej z walczących stron i zarówno zachodni alianci, jak i państwa centralne spodziewały się rychłego upadku Rosji. Skoro walki atakami frontalnymi przynosiły jedynie wykrwawianie się siły żywej i wzrost nastrojów pesymistycznych we wszystkich walczących krajach, przeto zachodni sojusznicy obmyślali koncepcję ataku ze skrzydła i na słabszego z przeciwników. Obaj wielcy sojusznicy dysponowali stosowną przewagą na morzach. Pierwszy lord admiralicji Winston Churchill opowiadał się za morskim atakiem na Turcję, w szczególności na cieśniny i Stambuł (Konstantynopol), co pozwoliłoby uzyskać kontakt z Rosją i wspomóc ją dostawami zwłaszcza amunicji, zaś samemu pozyskiwać żywność z Ukrainy. Jak wiadomo, po jedenastu miesiącach od rozpoczęcia operacji, w styczniu 1916 r., sojusznicy wycofali się pokonani. Była to nie tylko przegrana bitwa, ale utrata prestiżu. Przede wszystkim zaś uzyskanie drogi do Rosji stało się niewykonalne, zaś Rosja ponosiła w tym czasie (lato 1915 r.) klęski na froncie europejskim: ofen-

\footnotetext{
${ }^{34}$ Aleksandr Fiodorowicz Kierenski (1881-1970), ur. w Symbirsku (później Uljanowsk), młodszy kolega szkolny Lenina (Włodzimierza Uljanowa); ukończył prawo na Uniwersytecie w Petersburgu (podobnie jak Lenin); bardzo popularny obrońca w procesach politycznych, deputowany do Dumy; wspaniały mówca, porywający tłumy; lider socjalistycznej lewicy, związany z socjalistami-rewolucjonistami (eserowcami); 1913 uwięziony; po rewolucji lutowej 1917 członek Tymczasowego Komitetu Dumy Państwowej, zastępca przewodniczącego Piotrogrodzkiej Rady Delegatów Robotniczych i Żołnierskich; od III 1917 minister sprawiedliwości; od 15 V 1917 minister wojny; od 21 VII 1917 premier Rządu Tymczasowego; od IX 1917 także naczelny wódz; VII 1917 po bolszewickiej próbie obalenia rządu zdelegalizował partie bolszewików, ale w obliczu zagrożenia zamachem ze strony Korniłowa wycofał się z tego i pomógł uzbroić bolszewików; usiłował zajmować pozycję centrową, ale nie rozwiązał żadnego rosyjskiego problemu miesięcy letnich 1917; uważany był za przychylnego dla narodowej sprawy ukraińskiej, ale też nie przyczynił się do jej rozwiązania; nietrafne były jego rozpoznania zagrożeń; w szczególności trzymał się Ententy i wszelkimi sposobami prowadził nadal wojnę, do czego Rosja już nie była zdolna, a społeczeństwo wyczerpane; po październikowym 1917 zamachu stanu bolszewickim zbiegł z Petersburga i bezskutecznie usiłował zorganizować kontruderzenie przeciwko rewolcie; w V 1918 wyjechał do Francji, od 1940 wykładowca w USA; autor prac o rewolucji lutowej; zmarł w Londynie. Zob. m.in. Leksykon historii świata, red. A. Bartnicki..., s. 203-204; G. Przebinda, J. Smaga, Kto jest kim w Rosji..., s. 136-137, passim.
} 
sywa niemiecka, rozpoczęła się 2 maja 1915 r. pod Gorlicami, a straszna klęska wojska rosyjskich zamieniła się $\mathrm{w}$ dalszym pościgu w niebywały pogrom ${ }^{35}$; potem druga ofensywa - rozpoczęta w lipcu - przyniosła Rosji kolejny pogrom i przesunęła linię frontu o 480 kilometrów ${ }^{36}$. Front w 1915 r. zatrzymał się na Dźwinie, na przedpolach Rygi; niemiecka flota wojenna wpłynęła do Zatoki Ryskiej. Jednak Rosja zadeklarowała ${ }^{37}$ gotowość wzięcia udziału w skoordynowanej ofensywie Ententy przewidywanej na 1916 r.; w Petersburgu wierzono w gigantyczne rezerwy ludzkie. W lutym 1916 r. Rosja uzyskała duży sukces na froncie kaukaskim, zdobywając twierdzę Erzerum, ale główny atak rosyjski rozpoczął się 18 marca 1916 r. z Białorusi w kierunku krajów bałtyckich oraz w kierunku jeziora Narocz na wschód od Wilna. Przewaga liczbowa wojsk rosyjskich była czterokrotna, a jednak ofensywa rosyjska zakończyła się znowu sromotną klęską ${ }^{38}$. Nic tu nie pomógł sukces ofensywy generała Aleksieja Brusiłowa ${ }^{39}$ na rosyjskim południowym froncie europejskim (Galicja Wschodnia, Wołyń), jedynej dużej zwycięskiej operacji rosyjskiej w I wojnie światowej. Jak niedaleka przyszłość pokaże, był to już ostatni liczący się sukces rosyjski w I wojnie światowej.

Rewolucja lutowa wszakże przyniosła m.in. zmianę nastrojów, i to tak w Rosji, jak i w gabinetach rządowych Europy i Waszyngtonu. W Londynie i Paryżu tylko

${ }^{35}$ Wystarczy przytoczyć, że w ciągu jednego miesiąca - do końca maja 1915 r. - armie rosyjskie straciły 410 tys. żołnierzy. Niemcy bez jednego wystrzału zajęli (3 VI 1915) twierdzę Przemyśl, której wcześniejsze zdobycie, kosztowało Rosjan wielki wysiłek. Popłoch w wojsku rosyjskim i tempo ucieczki były takie, że odsłonięte zostały skrzydła jednostek rosyjskich w Karpatach (co wymusiło również ich odwrót) oraz skrzydła jednostek na południe od Warszawy. W czerwcu siły austro-węgierskie odzyskały Lwów. Rosjanie utracili ogromne ilości sprzętu wojskowego, który dostał się w ręce nacierających. M.S. Neiberg, D. Jordan, Front wschodni 1914-1920. Od Tannenbergu do wojny polsko-bolszewickiej, słowo wstępne D. Showalter, tłum. J. Kozłowski, Poznań 2010, s. 78 i n.

${ }^{36}$ Rosjanie oddali Warszawę 5 VIII 1915 r., twierdzę w Brześciu 26 VIII, Wilno 19 IX. Szacuje się, że ponad 800 tys. żołnierzy armii rosyjskiej trafiło do niewoli albo zdezerterowało. Łącznie z ofensywą wiosenną 1915 r. szacunki mówią o utracie 2 mln żołnierzy armii rosyjskiej. M. S. Neiberg, D. Jordan, Front wschodni..., s. 83.

37 W grudniu 1916 r. w Chantilly pod Paryżem odbyła się narada przedstawicieli ententy w kwestii podjęcia ofensywy na wszystkich frontach. M.S. Neiberg, D. Jordan, Front wschodni..., s. 86.

${ }^{38}$ Rosjanie stracili 100 tys. żołnierzy, Niemcy 20 tys. M. S. Neiberg, D. Jordan, Front wschod$n i \ldots$, s. 90 .

${ }_{39}$ Aleksiej Brusiłow (1853-1926), urodzony w Tyflisie, w rodzinie generała; w czasie I wojny światowej najpierw dowódca armii, wsławiony jedynym wielkim sukcesem carskiej armii przeciwko wojskom austro-węgierskim (VI-VII 1916); rok później (VII 1917) Brusiłow dowodził drugą dużą ofensywą rosyjską (tzw. druga ofensywa Brusiłowa albo ofensywa Kiereńskiego); ta jednak zakończyła się sromotną klęską Rosjan; V-VII 1917 wódz naczelny wojsk rosyjskich; podjął współpracę z bolszewikami jako tzw. wojenspec, m.in. w czasie wojny bolszewicko-polskiej 1920, później inspektor kawalerii ZSRR. Zob. zwłaszcza G. Przebinda, J. Smaga, Kto jest kim w Rosji ..., s. 41; Leksykon historii świata: Rosja ..., s. 46-47; M.S. Neiberg, D. Jordan, Front wschodni..., s. 91-136; Leksykon historii powszechnej..., s. 54; Leksykon historii świata, red. A. Bartnicki..., s. 57. 
kilka dni po abdykacji mogły być nerwowe, gdyż Rząd Tymczasowy pospieszył z deklaracjami dotrzymania zobowiązań sojuszniczych i kontynuowania wojny, w szczególności niezawierania odrębnego pokoju. Zaraz nastąpił przypływ pozytywnej energii i w Rosji, i w na Zachodzie: $\mathrm{z}$ rewolucyjną zmianą w bardzo podupadłej poprzednio Rosji wszyscy łączyli duże nadzieje, niemal oczekiwali cudu prawie niezwłocznie. Entuzjazm wiosennych tygodni 1917 r. mógł wykształconym historykom przywoływać na myśl wydarzenia francuskie sprzed 125 laty, ale różnica wszak była zasadnicza: w końcu XVIII nie było jeszcze karabinów maszynowych i czołgów, a w 1917 r. rewolucyjny zapał nie mógł tych urządzeń do zabijania zastąpić. $Z$ zapałem jednak przystąpiono w Rosji do przygotowywania wielkiej ofensywy, a zadanie to otrzymał ponownie Brusiłow. Propagandą wojenną i patriotyczną zajął się osobiście minister wojny Kiereński. Mimo zgromadzenia wielkich si $^{40}$, strona rosyjska była do wielkiej wojny przygotowana tylko w ograniczonym zakresie. Braki były w uzbrojeniu i braki były w kasie państwowej, a bez pieniędzy Rosjanie ówcześnie nie mogli nic kupić u swoich sojuszników. Emisja „bonów wolności” jako pożyczki wojennej od społeczeństwa poniosła fiasko, bo biedni byli za biedni, by je kupować, a bogaci nie wierzyli, że pieniądze odzyskają ${ }^{41}$. Na fali entuzjazmu marca, w nurcie rozdawania uprawnień i ogólnej liberalizacji widzieć trzeba decyzję rządu z 25 marca 1917 r. o całkowitym zniesieniu kary śmierci. W warunkach wojny i znacznego rozprężenia w kraju decyzja to zaiste zaskakująca. W istocie naiwna w swoim utopijnym charakterze, w przekonaniu, iż teraz wszystko będzie dobrze. Entuzjazm marcowych dni powoli jednak przemijał, zaś ciężary codziennego bytowania w wojennej rzeczywistości nie znikały.

Trzeba wziąć pod uwagę, że w ówczesnych realiach piotrogrodzki Rząd Tymczasowy nie był w stanie podejmować samodzielnych decyzji. Wyższe organy administracji byłego cesarstwa rozpadły się. Faktyczną władzę w Piotrogrodzie przejęła Rada Delegatów Robotniczych i Żołnierskich, za którą opowiedzieli się żołnierze załogi stolicy. Była to potężna siła zbrojna. Więc nie Rząd Tymczasowy, lecz Rada będąca instytucją nieformalną dysponowała siłą zbrojną. Wieczorem 14 marca 1917 r. pod naciskiem żołnierzy Rada wydała „Rozkaz Nr. 1”, którym zaprowadzała w siłach zbrojnych lądowych i we flocie komitety wojskowe jako instytucje reprezentujące żołnierzy i marynarzy. Od tej chwili jednostki wojskowe podlegały wyłącznie rozkazom rad delegatów robotniczych i żołnierskich. Prawdziwym wstrząsem dla wojska okazała się ta część rozkazu w której zadecydowa-

${ }^{40}$ Brusiłow zgromadził do tej ofensywy 31 dywizji i skoncentrował je na południu, naprzeciw 2 i 3 armii austro-węgierskiej na strategicznym kierunku pól naftowych Drohobycza i dalej w kierunku Lwowa, którego zdobycie miałoby poprawić morale armii i podnieść prestiż strony rosyjskiej. M.S. Neiberg, D. Jordan, Front wschodni..., s. 126-128.

${ }^{41}$ M.S. Neiberg, D. Jordan, Front wschodni..., s. 128. 
no o zaprowadzeniu wyborów oficerów przez podległe im jednostki ${ }^{42}$. Dowództwo wojskowe zupełnie straciło autorytet i wpływ nad masę żołnierską. Wielomilionowa armia carska pogrążyła się w chaosie, paraliżując zarazem wojskową, jak i cywilną administrację. Radykalna propaganda bolszewików za zakończeniem wojny właśnie w wojsku odnosiła sukcesy największe, bo też żołnierzom przychodziło doświadczać wojny najstraszniej. Wzmocnić dyscyplinę, przywrócić karność wojska trzeba było bezwzględnie i trudno się dziwić, że Kiereński zabronił (czerwiec 1917 r.) Ukraińcom odbycia drugiego zjazdu wojskowego, jak i w ogóle wszelakich wieców wojskowych. Na żadne demonstracje zgodzić się nie było rządowi wolno, a takich wszak nie brakowało i w wojsku, i wśród ludności cywilnej. Minister wojny Kiereński, znakomity mówca, w okopach przemawiał do żołnierzy, zagrzewając ich do walki i obiecując rychłe zakończenie wojny ${ }^{43}$.

Rozpoczęta 18 czerwca/1 lipca 1917 r. ofensywa, zwana drugą ofensywą Brusiłowa albo ofensywą Kiereńskiego tylko początek miała bardzo udany ${ }^{44}$, ale po wsparciu wojsk austro-węgierskich silami niemieckimi zakończyła się kolejną już w tej wojnie koszmarną klęską strony rosyjskiej ${ }^{45}$. Czerwcowa/lipcowa

${ }^{42}$ История СССР (XIX-XX в.): Учебник. Под. ред. Й. А. Федосов,. Москва 1981, s. 381.

${ }^{43}$ Warto zacytować fragment tego przemówienia, gdyż odbija ono problemy wewnętrzne, nie tylko wojskowe, Rosji: „Proces przechodzenia od zniewolenia do wolności nie przebiega tak, jak powinien. Zasmakowaliśmy wolności i jesteśmy nią nieco upojeni. Potrzeba nam teraz trzeźwości i dyscypliny. Mogliście znosić cierpienia w milczeniu przez dziesięć lat i słuchać rozkazów znienawidzonego rządu. Mogliście nawet strzelać do swoich, kiedy przychodził taki rozkaz. A teraz nie stać was na to, żeby dłużej cierpieć? Słyszymy, że podobno nie potrzebujemy już frontu, bo tam się bratają. Ale czy dzieje się tak na wszystkich frontach? Bratają się na francuskim froncie? Nie, towarzysze, jeśli macie się bratać, to wszędzie. Czyż siły nieprzyjaciela nie są przerzucane na brytyjsko-francuski front i czy natarcie brytyjsko-francuskie nie zostało już powstrzymane? Nie ma czego takiego, jak „front rosyjski”, jest jeden ogólny front sprzymierzonych. Maszerujemy ku pokojowi i nie znalazłbym się w szeregach Rządu Tymczasowego, gdyby zakończenie wojny nie było celem całego Rządu Tymczasowego [...]”. Cyt. za: M.S. Neiberg, D. Jordan, Front wschodni..., s. 133.

${ }^{44}$ Siły rosyjskie miały przed sobą armie austro-węgierskie, których jakość opisał kiedyś Jaroslav Hašek w opowieściach wojaka Szwejka. Brusiłow zaś na pierwsze uderzenie (18 czerwca/1 lipca 1917) przeznaczył legion czesko-słowacki, tworzący dwie doborowe brygady w armii rosyjskiej, złożony z byłych jeńców. Pomysł rosyjskiego wodza okazał się bardzo udany. Pułki czeskie w armii austro-węgierskiej, łącznie ponad 3 tys. żołnierzy, nie chcąc walczyć ze swoimi braćmi, odmówiły wykonania rozkazów i po prostu zdezerterowały, przy czym część z nich przeszła na stronę rosyjską. Dwie armie austro-węgierskie załamały się zupełnie i w panice uciekały otwierając ponad 70-kilometrową wyrwę w linii frontu. W ciągu dwóch tygodni Rosjanie wzięli dużą liczbę jeńców oraz zdobyli dużo sprzętu wojskowego; uchwycili drogi prowadzące do Lwowa. Swoją wielkość dowódcy potwierdził Ławr Korniłow. M.S. Neiberg, D. Jordan, Front wschodni..., s. 132-134; por. też J. Pajewski, Pierwsza wojna światowa 1914-1918, Warszawa 1991, s. 618.

45 Już w dwa tygodnie po rozpoczęciu rosyjskiej ofensywy kontratak na prawą (północną) flankę wojsk rosyjskich przypuściła niemiecka grupa armii z udziałem dywizji austro-węgierskich. Siłom rosyjskim kończyło się zaopatrzenie. Brusiłow nakazał odwrót, który zamienił się w ucieczkę, niekiedy paniczną. Chory Brusiłow został zastąpiony Korniłowem. Armia rosyjska była w komplet- 
(18 VI/1 VII) 1917 r. ofensywa, podjęta wszak głównie dla poprawienia morale wojska, a zakończona kompromitującą klęską i pokazem moralnego upadku armii (głównie mas żołnierskich), jej ducha bojowego, nie mogła pozostać bez skutków w kraju, w tym na Ukrainie będącej bezpośrednio obszarem frontowym. Kiedy po dymisji księcia Lwowa (20 lipca 1917 r.) obowiązki premiera nazajutrz przejął Aleksandr Fiodorowicz Kiereński, socjalista (eserowiec), ministrem wojny w jego rządzie został też eserowiec, słynny były terrorysta Borys Wiktorowicz Sawinkow ${ }^{46}$. Kiereński - wydaje się - był chyba jednak niezdecydowany, kogo

nej rozsypce; dezercja była wręcz powszechna i nie mogło temu zapobiec masowe stosowanie kary śmierci. Nastąpiła jej skrajna demoralizacja. Opuszczając ostatni skrawek Galicji nad Zbruczem, rosyjskie „wojska rewolucyjne” dopuszczały się barbarzyńskich pogromów ludności cywilnej. Dowódca 34 korpusu generał Paweł Skoropadśki w swoich wspomnieniach zanotował: „Rabunki, morderstwa, gwałty i inne bezeceństwa stały się zwyczajnym zjawiskiem [...]. W jaki sposób mógł zaradzić temu sztab i ja, skoro to komitety były prawdziwymi gospodarzami”. П. Скоропадський, Спогади. Кінець 1917 - грудень 1918, Київ-Філадельфія 1995, s. 68; M. S. Neiberg, D. Jordan, Front wschodni..., s. 135-137.

${ }^{46}$ Borys Wiktorowicz Sawinkow (1879-1925) urodził się w Charkowie w rodzinie prokuratora wojskowego, po 1881 ojciec jego przeniesiony został do Warszawy na stanowisko sędziego; Borys uczył się w Warszawie, studiował kulturę i historię Polski, mówił dobrze po polsku; nawiązał kontakty z Polską Partią Socjalistyczną; studia rozpoczął na wydziale prawa uniwersytetu w Petersburgu, po dwóch latach relegowany za działalność polityczną (poparł studentów Warszawy protestujących przeciwko odsłonięciu pomnika Michaiła Murawjowa-Wieszatiela); studia kontynuował w Berlinie i Heidelbergu; wykształcony, inteligentny, o wybitnych zdolnościach organizacyjnych; 1900 wrócił do Rosji; pisał o konieczności wykształcenia zawodowej elity rewolucjonistów; 1903 zbiegł za granicę i w Genewie poznał Jewno Azefa, który w tym czasie stanął na czele Wydziału Bojowego Partii Socjalistów-Rewolucjonistów [S-R; eserowcy] (a który - jak się później 1908 okazało - był jednocześnie agentem Ochrany); wspólnie z Azefem dokonał zamachu na ministra spraw wewnętrznych Wiaczesława Plehwego (zabity 1904), uczestniczył w zamachach na wielkiego księcia Sergiusza - generała-gubernatora Moskwy i popa Georgija Gapona (zabici w 1905-1906) i inne; aresztowany 1906 przy nieudanym zamachu zbiegł z więzienia za granicę; za granicą napisał główne książki swojego życia dot. psychologii terroryzmu, a także autobiograficzne, w których m.in. wyraził rozczarowanie słabymi skutkami terroru politycznego; 1914-1917 służył jako ochotnik w armii francuskiej; po rewolucji lutowej wrócił do Rosji i przez Kiereńskiego został mianowany komisarzem Rządu Tymczasowego przy Kwaterze Głównej i od IX 1917 ministrem wojny; popierał Korniłowa w czasie podjętej przez niego próby zamachu stanu; w kołach politycznych Piotrogrodu mówiło się o planowanej kolektywnej dyktaturze Korniłowa, Sawinkowa i Kiereńskiego; po upadku puczu Korniłowa został usunięty z Partii S-R. Po rewolucji październikowej stanął na czele antybolszewickiego Związku Obrony Ojczyzny i Wolności, przygotowywał zamachy na Lenina i Trockiego, agitował wśród chłopów na prowincji; na początku 1918 uczestniczył w tworzeniu Armii Ochotniczej na Kubaniu, pod nadzorem Korniłowa, a następnie Denikina; w VII 1918 po wybuchu w Moskwie powstania lewicowych eserowców zorganizował antybolszewickie powstania w Jarosławiu nad Wołgą, Muromiu i Rybińsku, zaś po ich zdławieniu i wprowadzeniu przez bolszewików czerwonego terroru organizował grupy terrorystyczne i kierował licznymi akcjami dywersyjnymi; przez Japonię wyemigrował (1919) do Europy, gdzie organizował pomoc dla Kołczaka i Denikina. W 1920 przybył do Warszawy i w kontakcie z Józefem Piłsudskim organizował działalność antybolszewicką; współpracował z organizatorem białej partyzantki na Białorusi - Stanisławem 
należy obawiać się bardziej: bolszewików czy monarchistów, zamachu na lewicy czy na prawicy. W istocie groziły oba. Na froncie zaś, w obliczu klęski armii i panicznej ucieczki zrewoltowanych oddziałów, Rząd Tymczasowy postanowił przywrócić (25 lipca 1917) karę śmierci i nowy głównodowodzący frontem Ławr Korniłow $^{47}$ nader często ją stosował.

\section{SYTUACJA WEWNĘTRZNA OD CZERWCA/LIPCA 1917 ROKU}

Pomimo zakazu ministra wojny Kiereńskiego, II Ogólnoukraiński Zjazd Wojskowy odbył się jeszcze 5-10/18-23 czerwca 1917 r., czyli tuż przed rozpoczęciem wspomnianej drugiej ofensywy Brusiłowa. Rząd Tymczasowy w Piotrogrodzie zupełnie nie panował nad wojskowymi ukraińskimi, czego dowodem decyzje oraz żądania tego bardzo licznie (ponad 2500 osób) obesłanego zjazdu. Uczest-

Bułak-Bałachowiczem; w 1921 zmuszony do wyjazdu z Polski na skutek noty protestacyjnej rządu radzieckiego; od 1921 w Paryżu poszukiwał pomocy u Mussoliniego. Agentom OGPU (bezpieki) udało się zwabić go do potajemnego przybycia do ZSRR 16/17 VIII 1924 celem rzekomego objęcia przywództwa konspiracyjnej opozycji; aresztowany VIII 1924 w Mińsku; przebywał na Łubiance; złamany w śledztwie zeznawał na procesie zgodnie z instrukcjami bezpieki; sąd pod przewodnictwem Wasilija Ulricha skazał go na karę śmierci, zamienioną „za zasługi w walce z caratem” na 10 lat pozbawienia wolności; 17 V 1925 według wersji oficjalnej popełnił samobójstwo: ,na oczach strażników wypadł” z okna V piętra na Łubiance, prawie na pewno został wyrzucony przez czekistów. M. Smoleń, [w:] EBP XVI 114-117; G. Przebinda, J. Smaga, Kto jest kim w Rosji po 1917 roku..., s. 252-252; Leksykon historii świata: Rosja..., s. 232; Leksykon historii powszechnej..., s. 397; B. Urbankowski, Józef Piłsudski - marzyciel i strateg, Poznań 2014, passim; A.S. Kowalczyk, Sawinkow, Warszawa 1992.

${ }^{47}$ Ławr Gieorgijewicz Korniłow (1870-1918) urodził się koło Karagandy (Kazachstan) jako syn oficera, pochodził z rodziny kozackiej, absolwent szkoły artylerii i Akademii Sztabu Generalnego, znał języki turecki, perski, chiński; uczestnik wojny rosyjsko-japońskiej (1904-1905); attaché wojskowy w Chinach; w czasie I wojny dowódca dywizji, potem korpusu; ranny trafił do niewoli austriackiej, z której brawurowo uciekł, co przydało mu popularności; po rewolucji lutowej dowódca piotrogrodzkiego okręgu wojskowego, odpowiedzialny za ochronę rodziny byłego cara; 19 lipca (1 sierpnia) 1917 roku mianowany naczelnym wodzem całości sił rosyjskich; w czasie ofensywy w VI 1917 w obliczu panicznej ucieczki całych oddziałów rosyjskich zażądał przywrócenia przez rząd kary śmierci na froncie, co uzyskał; jako jedyny z carskich generałów prezentował poglądy demokratyczne, co wydawało się do zaakceptowania dla Rządu Tymczasowego i w jakimś porozumieniu z Kiereńskim, w celu „opanowania w Rosji anarchii”, wysłał siły wojskowe dla spacyfikowania stolicy z jej zdemoralizowanym dużym garnizonem, ale premier rządu wycofał się z ustaleń i pucz się nie udał, zaś Korniłow został na polecenie rządu aresztowany; po zamachu bolszewickim zbiegł (XII 1917) z aresztu i udał się nad Don; był jednym z organizatorów i głównodowodzącym Armii Ochotniczej na południu Rosji, głównej wojskowej formacji białych; zginął w czasie szturmu na Jekatierinodar. J. Smaga, [w:] G. Przebinda, J. Smaga, Kto jest kim w Rosji..., s. 146; Leksykon historii świata: Rosja..., s. 140; WEP XIV 391; A. Kijas, [w:] Leksykon historii powszechnej..., s. 217; Leksykon historii świata, red. A. Bartnicki..., s. 218; P. Wieczorkiewicz, [w:] L. Bazylow P. Wieczorkiewicz, Historia Rosji, wyd. 4, Wrocław-Warszawa-Kraków 2005, s. 382. 
nicy uznali zakaz odbycia zjazdu za nielegalny; zażądali od Centralnej Rady, by przystąpiła do tworzenia państwa ukraińskiego bez oglądania się na zgodę Piotrogrodu; wybrali Ogólnoukraińską Radę Delegatów Żołnierskich; zażądali, by obrany na pierwszym zjeździe Ukraiński Wojskowy Komitet Generalny z Symonem Petlurą na czele przystąpił do tworzenia ukraińskich sił zbrojnych, jak też powołano wojskową formację ochotniczą pod nazwą Wolnego Kozactwa, która w istocie była tworzona już wcześniej, a organizowano ją na zasadach terytorialnych, zaś oficerów wybierano; atamanem tej formacji w październiku został wybrany gen. Paweł Skoropadśki. Formacja Wolnego Kozactwa podporządkowana została Sekretariatowi Generalnemu (rządowi) UCR, najpierw sekretariatowi spraw wewnętrznych, potem wojny; rozwijała się żywo i wkrótce liczyła już ok. 60 tys. żołnierzy; została zlikwidowana w marcu-kwietniu 1918 r. na żądanie wojskowych władz niemieckich ${ }^{48}$.

Wskutek załamania się ofensywy wojsk rosyjskich na froncie w lipcu 1917 r. władze wojskowe zdecydowały się na oficjalne zezwolenie na ukrainizację niektórych formacji, w tym nie tylko zapasowych, ale również frontowych. Chodziło o wykorzystanie Ukraińców jako elementu stabilizującego front. 3/16 sierpnia wódz naczelny armii rosyjskiej generał Korniłow wydał rozkaz o przeprowadzeniu ukrainizacji dziesięciu dywizji. Tak rozpoczął się drugi etap ukrainizacji, sankcjonowany przez kwaterę główną. Zaczęły się tworzyć największe formacje ukraińskie; m.in. 40-tysięczny I Korpus Ukraiński pod dowództwem generała Pawła Skoropadśkiego. Ukrainizacja wojska pod koniec lata 1917 r. postępowała w szybkim tempie, obejmując blisko 120 tys. żołnierzy i oficerów ${ }^{49}$. W rezultacie wojska dyslokowane na terenie Ukrainy przekształciły się w terytorialne, w istocie w ukraińskie jednostki narodowe. Centralna Rada jednak, trzymając się nadal koncepcji federalistycznej, wciąż nie chciała skorzystać z szansy tworzenia regularnych sił zbrojnych. Proponowała zastąpić je formacjami milicyjnymi na kształt pospolitego ruszenia, chociaż realia powinny były liderom politycznym wskazywać na potrzebę tworzenia regularnego wojska. Tymczasem ukrainizowane formacje tak się rozbudowały, że powstała potrzeba tworzenia odrębnej struktury administracji wojskowej.

Bardzo niespokojna była ukraińska wieś, gdzie reforma rolna stała się sprawą niemożliwą do uniknięcia i domagały się jej wszystkie ugrupowania, z mającymi największe wpływy Związkiem Chłopskim (socjaliści-rewolucjoniści) oraz Ukraińską Partią Demokratyczno-Chłopską. Na razie jednak wieś nie miała znaczenia dla rozgrywek w sprawie narodowej i trochę przez czołowych polityków ukra-

\footnotetext{
${ }^{48}$ W. Serczyk, Historia Ukrainy..., s. 254-255.

49 Центральний державний архів вищих органів влади України, ф. 1076 (Генеральне секретарство по справах військових), оп. 1, спр. 9, s. 3.
} 
ińskich była ignorowana. Jednak w sierpniu-wrześniu 1917 r. trzeba było użyć wojska z rosyjskiego Frontu Południowo-Zachodniego dla pacyfikowania wsi ukraińskich. Z biegiem czasu ludność wiejska, wszak liczebnie znacznie przeważająca ${ }^{50}$, będzie odgrywała coraz większą rolę w rozwoju zdarzeń; będzie się też radykalizowała i ulegała wpływom bolszewickim.

Nie tylko akceptacja, ale wręcz presja potężnego zjazdu wojskowych była skuteczna. Jak już wspomniano, w ostatnim dniu zjazdu (10/23 czerwca 1917 r.) Ukraińska Centralna Rada ogłosiła tzw. I Uniwersat, w którym proklamowała autonomię Ukrainy ${ }^{51}$ i wkrótce utworzyła Sekretariat Generalny, będący w istocie rządem $^{52}$. Redakcję dokumentu przygotował Wołodymyr Wynnyczenko; on też stanął na czele Sekretariatu Generalnego i objął również tekę (sekretariat) spraw wewnętrznych. $Z$ delegacją Sekretariatu Generalnego z Wynnyczenko na czele spotkała się (28 czerwca/11 lipca 1917 r.) reprezentacja Rządu Tymczasowego z Kiereńskim, która przybyła na rozmowy do Kijowa, co podkreślało wagę, jaką w Piotrogrodzie przywiązywano do spraw ukraińskich, a także mogło być traktowane jako uznanie de facto rządu ukraińskiego. Kiereński jeszcze wówczas nie był premierem, tylko ministrem wojny, ale od dłuższego czasu faktycznie był czołową postacią gabinetu, a nadto uważany był za ukrainofila. W dwa dni później (30 czerwca/13 lipca) stanęła ugoda między UCR a Rządem Tymczasowym. Za cenę odłożenia sprawy autonomii do zwołania ogólnorosyjskiego zgromadzenia ustawodawczego oraz za oficjalne poparcie dla Rządu Tymczasowego UCR uzyskiwała status przedstawicielki rządu w pięciu (z dziewięciu) guberniach ${ }^{53}$, do których rościła pretensje. Wkrótce się okaże, że rząd interpretował wspomniany status przedstawicielki rządu jako obowiązek wykonywanie poleceń Rządu piotrogrodzkiego ${ }^{54}$. UCR m.in. otrzymała prawo do tworzenia swoich rad, a nadto

${ }^{50}$ W latach 1919-1920 Ukraina liczyła ok. 26 mln mieszkańców, z czego 4,6 mln żyło w miastach: Kijów 360 tys., Charków 270 tys., największa Odessa 485 tys. Podaję za P. Brouẻ, Między Trockim a Stalinem. Chrystian Rakowski - biografia polityczna, thum B. Panek, Wrocław-Warszawa-Kraków 1999, s. 119.

${ }_{51}$ Zob. Історія держави і права Украӥни..., t. 2 , s. 43; История отечественного государства и права, ч. 1, s. 456.

${ }^{52}$ Історія держави і права України..., t. 2 , s. 43; История отечественного государства и права, ч. 1, s. 456.

${ }^{53}$ Kijowskiej, podolskiej, połtawskiej, wołyńskiej i części czernihowskiej. Nie dotyczyło to w szczególności guberni charkowskiej, jekaterynosławskiej i guberni południowych. Icmopiя держави і права України..., t. 2 , s. 46; История отечественного государства и права..., ч. 1, s. 456.

${ }^{54}$ Oto fragmenty tymczasowej instrukcji Rzadu Tymczasowego dla Sekretariatu Generalnego UCR z 4 VIII 1917: „1) Do czasu rozstrzygnięcia przez Zgromadzenie Ustawodawcze kwestii rządu lokalnego, Sekretariat Generalny, mianowany przez Rząd Tymczasowy na propozycję Centralnej Rady, będzie działać jako najwyższy organ Rządu Tymczasowego w sprawach administracji lokalnej na Ukrainie. 2) Pełnomocnictwa Sekretariatu Generalnego obejmują gubernie: kijowską, 
reprezentanci UCR mieli się znaleźć w ministerstwie wojny, naczelnym dowództwie wojskowym oraz sztabie generalnym ${ }^{55}$. Sekretarze obowiązani byli wykonywać polecenia Rządu Tymczasowego, ale ponosić mieli odpowiedzialność przed Centralną Radą, która miała prawo ich zmienić. Wszystkie organy administracji w pięciu guberniach podlegały Sekretariatowi Generalnemu ${ }^{56}$. Ugoda przewidywała jeszcze jedną istotną sprawę. Strona ukraińska godziła się na dopełnienie składu Rady przedstawicielami mniejszości narodowych, liczba których miała być proporcjonalna do liczby ludności nieukraińskiej. W wyniku pertraktacji ukraińsko-rosyjskich ustalono ją na $30 \%$ miejsc w $\mathrm{UCR}^{57}$. Został również reorganizowany Generalny Sekretariat. Różnica jednak polegała na tym, że przy tym brano pod uwagę kryterium fachowe, więc nie uwzględniano żadnych kwot procentowych w czasie jego formowania. Wszakże dla ochrony praw ludności nieukraińskiej zdecydowano powołać obok sekretarza do spraw międzynarodowych trzech jego zastępców - Rosjanina, Żyda i Polaka. Mieli oni stać na straży tych trzech najliczniejszych mniejszości narodowych na Ukrainie. Ugodę wraz z poparciem dla Rządu Tymczasowego opublikowano w II Uniwersale Rady.

Było to uznanie de facto autonomii Ukrainy ze strony rosyjskiego Rządu Tymczasowego, chociaż z daleko idącymi ustępstwami ze strony ukraińskiej, bowiem o formalnym ustanowieniu autonomii Ukrainy miała zadecydować rosyjska konstytuanta (wszechrosyjskie zgromadzenie ustawodawcze). Właśnie to ostatnie ustępstwo wywołało ostrą krytykę ze strony prawicowych sił nacjonalistycznych, tzw. niepodległościowców, których liderem był Mykoła Michnowśkyj ${ }^{58}$, cieszą-

wołyńską, podolską, połtawską i czernihowską z wyjątkiem powiatów: mglinskiego, surażskiego, starodubowskiego i nowozybkowskiego. [...] 3) Sekretariat Generalny składa się z sekretarzy generalnych następujących departamentów: a) spraw wewnętrznych, b) finansów, c) rolnictwa, d) oświaty, e) handlu i przemysłu, f) pracy, a także generalnego sekretarza do spraw narodowościowych i generalnego urzędnika. [...] 6) We wszystkich sprawach [...] miejscowe władze kraju powinny zasięgać opinii Sekretariatu Generalnego, który po porozumieniu się z Rządem Tymczasowym, przekaże miejscowym władzom dyrektywy i zarządzenia tego ostatniego. [...]”. Cyt. za: R. Pipes, Czerwone imperium ..., s. 66-67; zob. też na temat odmiennej interpretacji obu stron [w:] История отечественного государства и права..., ч. 1, s. 456; Історія держави і права України..., t. 2, s. 45.

${ }^{55}$ W. Serczyk, Historia Ukrainy..., s. 257.

${ }^{56}$ Історія держави і права Украӥни..., t. 2 , s. 45; История отечественного государства и права..., ч. 1, s. 456.

57 М.Грушевський, Украӥнаі Росія. Переговорив справіновоголаду (липень-серпень 1917 р.) [w:] Хто такі українці і чого вони хочуть?, Київ 1991, s. 33.

${ }^{58}$ Mykoła Michnowśkyj (Michnowski) 1873-1924; ukr. polityk i ideolog; ukończył prawo w Kijowie; adwokat w Charkowie, obrońca w procesach politycznych; napisał (1900) program Ukr. Partii Rewolucyjnej, w którym po raz pierwszy zgłoszono postulat niepodległości Ukrainy; 1901/2 współinicjator Ukr. Partii Narodowej skupiającej zwolenników zbrojnej walki o niepodległość; w publicystyce przedstawił główne zasady ukr. nacjonalizmu; w programie UPN nakreślił wizję wolnej, demokratycznej ukraińskiej republiki ludzi pracy od Karpat po Kaukaz; ziemia na włas- 
cych się poparciem sfer wojskowych. Nie uznali II Uniwersału i zdecydowali się na powstanie antyrosyjskie w Kijowie. Według planu mieli zająć gmachy urzędowe w mieście, wymusić na Centralnej Radzie proklamowanie niepodległości Ukrainy i niezwłocznie podpisać separatystyczny pokój z państwami centralnymi. Michnowskiemu i jego grupie udało się zbuntować jeden pułk ukraiński i w dniach 17-20 lipca 1917 r. obsadzić szereg ważnych gmachów urzędowych ${ }^{59}$. Powstanie zostało stłumione bez ofiar siłami rządowymi i ukraińskim pułkiem imienia Chmielnickiego, którym dysponowała Centralna Rada. Była to akcja polityczna, która miała na celu przeprowadzenie swoistego zamachu stanu. Osobliwość tego zamachu polegała na tym, że nie był wymierzony przeciwko Centralnej Radzie jako wyższemu narodowemu organowi władzy i nie miał na celu usunięcie jej z areny politycznej, lecz odwrotnie: zamachowcy po zdobyciu stolicy i uwolnienia jej od miejscowych agend rosyjskiego rządu planowali wymusić na Radzie ogłoszenie się suwerenną władzą na Ukrainie i proklamowanie niepodległości. Należy mieć na uwadze, że lojalna postawa Centralnej Rady wobec Rządu Tymczasowego ograniczała możliwości realizacji autonomii Ukrainy. 16/29 lipca 1917 r. Centralna Rada uchwaliła projekt Statutu wyższego zarządu Ukrainy. Można to traktować jako krok w kierunku przekształcenia się UCR w najwyższy organ władzy terytorialnej na Ukrainie. UCR nie powstała w wyniku wyborów powszechnych, lecz składała się z delegatów rozmaitych organizacji społecznych i przedstawicieli wyłonionych z różnego rodzaju zjazdów. Jednak jej skład odzwierciedlał sytuację społeczną i polityczną ówczesnej Ukrainy.

W II Uniwersale znalazła się także zapowiedź rozwiązania kwestii agrarnej, która była - jak zresztą w całej dotychczasowej Rosji - wielkim problemem socjalnym, a na Ukrainie nieustannie wywoływała niepokoje społeczne.

Porozumienie między UCR a Rządem Tymczasowym (30 czerwca/13 lipca) mogło wydawać się dobre, rokujące spokojne rozwiązanie zarówno spraw narodowych, jak i socjalnych owych dni, ale rosła temperatura nastrojów zarówno społecznych, jak i narodowych, na co nakładała się nieporadność rządu w Piotrogrodzie i klęski wojenne. Zwrócić należy uwagę, że strona ukraińska występowała dotychczas nader jednolicie, mimo mozaiki tworzących Centralną Radę

ność chłopów; 1903 stworzył przy UPN paramilitarną organizację, która zorganizowała kilka akcji terrorystycznych; w czasie I wojny zmobilizowany do armii carskiej; III 1917 wysunął koncepcję tworzenia ukr. sił zbrojnych; inicjator m.in. Wojskowego Komitetu Organizacyjnego, z ramienia którego wszedł do UCR, gdzie konsekwentnie opowiadał się za niepodległością; w opozycji do rządów hetmańskich; znalazł się na terenach opanowanych przez bolszewików; 1924 resztowany przez GPU; według jednej wersji rozstrzelany, według innej powiesił się, a prawdopodobnie samobójstwo było zainscenizowane przez GPU. B. Berdychowska, [w:] Stownik biograficzny Europy Środkowo-Wschodniej..., s. 827-828.

${ }_{59}$ М. Грушевський, Спомини, „Київ” (1989), nr 10, s. 147. 
polityków. Nie tak już było w Rządzie Tymczasowym w Piotrogrodzie, gdzie niektórzy ministrowie partii kadetów odmówili zgody na zawarte z Ukraińcami porozumienie i na znak protestu ustąpili z gabinetu.

W liczącej ponad 800 osób Radzie przedstawiciele bolszewików w zasadzie się nie udzielali; weszli do niej późno, bo dopiero w sierpniu 1917 r. i nie byli w niej widoczni. Bolszewicy do końca lata 1917 r. nie mieli też wpływu na wydarzenia na Ukrainie, poza jednak ogólną radykalizacją postaw w rozmaitych kręgach społecznych. Bolszewicy, tak ukraińscy, jak i piotrogrodzcy, nie mogli dla siebie znaleźć miejsca politycznego w toczących się bez ich udziału wydarzeniach. Byli wszak przeciwko Rządowi Tymczasowemu (który wkrótce obalą), ale to nie mogło dla nich znaczyć, że popierają UCR, która swoim wyraźnie nacjonalistycznym charakterem w żaden sposób nie przystawała do generalnego programu komunistów. Byli więc tylko przeciw wszystkiemu, a jedynie za walką $z$ burżuazją tak rosyjską, jak i ukraińską, z doskonale mętnymi uwagami na temat równych praw dla wszystkich narodowości. To ostatnie było ważne, gdyż ludność nieukraińska - Rosjanie, Żydzi bali się nacjonalizmu ukraińskiego i zwłaszcza wymienione grupy narodowe mogły optować na rzecz władzy w Piotrogrodzie, a byli jeszcze inni.

Jak długo narodowy ruch ukraiński mógł służyć osłabianiu Rządu Tymczasowego w Piotrogrodzie, tak długo jednak był dobry dla bolszewików. Lenin w czerwcu 1917 r. w wygłoszonym i następnie drukowanym w „Prawdzie” przemówieniu wsparł federacyjne żądania Ukraińców (i Finów), ganiąc rząd, „który nędznymi zaczepkami komplikuje sprawę z Ukrainą" ${ }^{60}$. Ruch narodowy programowo obcy był temu, co głosił Manifest komunistyczny i leninowska koncepcja dużych, scentralizowanych państw komunistycznych. Georgij Piatakow ${ }^{61}$,

${ }^{60}$ W. Lenin, Dzieła wybrane, KiW, T. II, Warszawa 1949, s. 59-60.

${ }^{61}$ Gieorgij Leonidowicz Piatakow (właśc. Kijewskij), ur. 1890 Horodyszcze k. Czerkasów w rodzinie robotniczej żydowskiej; ukończył studia ekonomiczne w Petersburgu i Europie Zachodniej; anarchista; od $1910 \mathrm{w}$ partii bolszewickiej; 1915-1917 polemizował z Leninem w kwestii narodowościowej, zajmując stanowisko bliskie Róży Luksemburg, mimo to przejściowo reprezentował 1917 kijowskich bolszewików w UCR; jeden z twórców rządu bolszewickiego na Ukrainie (II 1918); współtworzył Komunistyczną Partię (bolszewików) Ukrainy wchodzącą w skład Rosyjskiej Komunistycznej Partii (bolszewików); utracił władzę partyjną po niepowodzeniu powstania chłopskiego VIII 1918 na Ukrainie; po zakończeniu działań I wojny i po anulowaniu traktatu brzeskiego 20 listopada 1918 r. ogłoszono utworzenie Tymczasowego Rządu Robotniczo-Chłopskiego Ukrainy na czele z P.; 1919 odszedł z rządu ukr.; 1920-1923 dyrektor kopalń i innych dużych zakładów przemysłowych w Donbasie i na Uralu oraz zast. przew. Pań. Komisji Planowania RSFRR; od 1930 przew. Wszechzwiązkowej Rady Gospodarki Narodowej; 1923-1927 członek KC WKP(b); związany z Trockim; 1927 wydalony z partii i usunięty ze stanowisk; złożył samokrytykę i wrócił do KC oraz do Rady; twórca pierwszej pięciolatki, jako zast.lud.komisarza przem.ciężkiego odpowiadał za industrializację w toku drugiej pięciolatki i wyróżnił się drakońskimi metodami eksploatacji robotników; aresztowany jesienią 1936 i 1937 skazany na karę śmierci jako przywódca kolejnego 
w 1917 r. szef partii komunistycznej w rejonie kijowskim i przejściowo nawet członek UCR, mówił, że komuniści mają ,z jednej strony protestować przeciwko działaniom rządu, a zwłaszcza Kiereńskiego, z drugiej zaś walczyć z szowinistycznymi dążeniami Ukraińców"62.

Słabe były też reprezentacje bolszewików w radach delegatów, gdzie przeważali mienszewicy i eserowcy. Nastroje jednak w miarę upływających tygodni radykalizowały się. Jak wiadomo, w kwietniu do Rosji powrócił Lenin z dużymi niemieckim pieniędzmi. Lipcowa klęska tzw. ofensywy Kiereńskiego na froncie to klęska rządu z nieudolnym, chociaż dobrze na zewnątrz postrzeganym Kiereńskim w nowej roli premiera. Radykalizacja postępowała tak od lewej, jak i od prawej strony sceny politycznej. W lipcu 1917 r. zamachu stanu w stolicy spróbowali bolszewicy; nie udało się. Lenin zbiegł do Finlandii; partia bolszewicka była o krok od całkowitej likwidacji. Liderem gotowym dokonać zamachu stanu po prawej stronie został Korniłow. Kiereński wydawał się początkowo współdziałać z Korniłowem, ale zaniepokojony utratą kontroli zrobił polityczny zwrot i Korniłow został aresztowany. Bardzo aktywnie odreagowała na próbę ustanowienia dyktatury Korniłowa Centralna Rada, słusznie bowiem uważała, że jego zwycięstwo położy kres demokracji i zagrozi już osiągniętym zdobyczom na drodze do autonomii Ukrainy. S. Petlura rozesłał do ukrainizowanych jednostek wojskowych (ich liczbę na ten czas szacowano na około 120 tys. żołnierzy i oficerów ${ }^{63}$ ) telegram, w którym uprzedzał ich, że „zwycięstwo Korniłowa skutkowałoby rozłamem rosyjskiej demokracji i ponownym zniewoleniem Ukraińców”64. Żadna z ukraińskich jednostek wojskowych nie poparła zamachu i nie wykonała rozkazów Korniłowa. Na Ukrainie pozostający pod wpływem bolszewików żołnierze, likwidując jeden z ośrodków puczu Korniłowa, aresztowali m.in. generała Antona Iwanowicza Denikina ${ }^{65}$. Dla stłumienia puczu Centralna Rada powołała

centrum trockistowskiego; przyznał się m.in. do tworzenia ośrodków terrorystycznych też do prób odłączenia Ukrainy od ZSRR; wyrok wykonano 30 I 1937. T. Stryjek, [w:] Słownik biograficzny Europy Środkowo-Wschodniej..., s. 976; Leksykon historii świata: Rosja..., s. 198; G. Przebinda, J. Smaga, Kto jest kim w Rosji..., s. 218-219; Leksykon historii powszechnej..., s. 342; R. Conquest, Wielki terror, thum. W. Jeżewski, Warszawa 1997, s. 168-189 i passim; N. Werth, [w:] Czarna księga komunizmu. Zbrodnie, terror, prześladowania, wstęp do polskiego wydania K. Kersten, Warszawa 1999, s. 122, 180.

${ }^{62}$ Cyt. za: R. Pipes, Czerwone imperium..., s. 70.

${ }_{63}$ М. Френкин, Захват власти большевиками в России и роль тыловых гарнизонов армии. Подготовка и проведение октябрьского мятежа 1917-1918 г., Иерусалим 1982, s. 124.

${ }_{64}$ В. Голубко, Армія Украӥнської Народної Республіки 1917-1918..., s. 124.

${ }_{65}$ Anton Iwanowicz Denikin, ur. 1872 w Łowiczu, gdzie ojciec oficer carski odbywał służbę, z matki Polki. Ukończył Akademię Sztabu Generalnego; uczestnik wojny rosyjsko-japońskiej; generał od VI 1914; w czasie I wojny światowej dowodził dywizją, korpusem; po rewolucji lutowej 1917 szef sztabu naczelnego wodza (V-VI); m.in. dowódca frontu zachodniego; za poparcie planowanego zamachu stanu Korniłowa aresztowany; po rewolucji październikowej zbiegł nad Don 
27 sierpnia (9 września) Nadzwyczajny Komitet Ochrony Rewolucji, do którego weszli reprezentanci wszystkich środowisk demokratycznych, począwszy od bolszewików na skrajnej lewicy, a kończąc na przedstawicielach lokalnych agend rządu rosyjskiego. Charakterystycznie, że Komitet miał podwójne podporządkowanie - Centralnej Radzie i Rządowi Tymczasowemu. Jest to dowodem uznania pierwszej za najwyższy organ administracji na terenie Ukrainy. Faktycznie możemy mówić o dwuwładzy na Ukrainie. Przy tym administracja rosyjska mogła działać wyłącznie przy dobrej woli Centralnej Rady. 31 sierpnia (13 września) zakończyła się bezkrwawo i żałośnie próba prawicowego zamachu stanu. Efektem było proklamowanie republiki dekretem rządowym (1/14 września 1917 r. $)^{66}$ i kolejny kryzys gabinetowy, zakończony powołaniem dyrektoriatu, czyli przekazaniem całej władzy rządowej pięciu ministrom z premierem Kiereńskim na czele. Zauważyć warto, że usiłujący dotychczas zachować legalizm Rząd Tymczasowy i odkładający zmiany ustrojowe do decyzji przyszłego zgromadzenia konstytucyjnego, zdecydował się na tak zasadniczy krok, jak proklamowanie Rosji republiką.

Upadek Korniłowa to kolejna klęska nieudolnego rządu. Jeśli przypomnieć stan kraju, koszmarne klęski na froncie I wojny, niedostatki podstawowych dóbr spożycia, wręcz ruinę gospodarczą, inflację, która sięgnęła 1000\%, to łatwo zrozumieć zarówno rozłam w partii samego premiera - Partii Socjalistów-Rewolucjonistów (eserowców), jak też gwałtownie spadające społeczno-polityczne poparcie dla koalicjantów rządowych i wzrost notowań bolszewików, którzy jako jedyni nie skompromitowali się jeszcze udziałem w tak nieudolnym rządzie. Przyszedł ich czas, ale trzeba zauważyć, że przygotowywali się do niego dobrze i opanowanie władzy nie spadło im w darze losu. W szczególności na Ukrainie zintensyfiko-

(XII 1917), gdzie współorganizował Armię Ochotniczą; po śmierci gen. Korniłowa (IV 1918) objął dowództwo nad Armią Ochotniczą; podporządkował sobie Kozaków; od 1919 stanął na czele Sił Zbrojnych Południa Rosji (Armia Ochotnicza, Dońska, Kaukaska); podczas ofensywy A. Kołczaka na Ural D. zajął Zagłębie Donieckie i Ukrainę, a we wrześniu 1919 rozpoczął ofensywę na Moskwę zajmując m.in. Kurs i Orzeł. Dobry wojskowy, ale fatalny jako polityk, popełniał kardynalne błędy: wszędzie szedł z hasłami przywrócenia Rosji imperialnej, w niezmienionych granicach, czym robił sobie wrogów z sił narodowych (np. na Kaukazie, Ukraińców, Polaków), wszędzie też anulował bolszewicki dekret o ziemi, czym wrogo nastawiał chłopów. Rozbity pod Orłem wrócił na Krym; 1920 oddał dowództwo w ręce Wrangla. Wyjechał do Konstantynopola, Francji, a stamtąd - w obawie deportacji - do USA (1945). Pozostawił obszerne wspomnienia i analizy. WEP VII, s. 84; G. Przebinda, J. Smaga, Kto jest kim w Rosji po 1917 roku ..., s. 66; Leksykon historii świata: Rosja ..., s. 67; Leksykon historii powszechnej..., s. 92; Leksykon historii świata, red. A. Bartnicki..., s. 90.

${ }^{66}$ Tekst polski zob. m.in. [w:] Powszechna historia ustroju. Wybór źródet, wyd. A. Bereza, A. Fermus-Bobowiec, G. Smyk, W. P. Tekely, W. Witkowski, red. serii M. Kallas, Warszawa 2015, s. 303; toż [w:] Historia państwa i prawa. Wybór tekstów źródłowych..., s. 259-260; zob. История отечественного государства и права..., ч. 1, s. 437. 
wano propagandę partyjną oraz tworzono jednostki Czerwonej Gwardii, których liczba i liczebność rosły szybko ${ }^{67}$.

Tymczasem politycy ukraińscy byli świadomi paraliżu rządu centralnego i usiłowali wymusić na nim kolejne ustępstwa, które już jawnie wychodziły poza ramy autonomii. Generalny Sekretariat otwarcie dążył do przejęcia władzy nad zukrainizowanymi formacjami wojska nie tylko na tyłach, lecz i na froncie. 27 września 1917 r. delegacja Generalnego Komitetu Wojskowego odwiedziła rosyjską Kwaterę Główną w Pskowie i uzyskała jej zezwolenie na nieograniczoną ukrainizację armii. Była to w istocie legalizacja istniejących już wojskowych formacji ukraińskich. Zaczął się ostatni etap ukrainizacji armii, a jego skutkiem stało się wyłonienie ukraińskich sił zbrojnych. W rosyjskim sztabie generalnym ustanowiono urząd przedstawiciela Centralnej Rady dla ułatwienia koordynowania działalności przy formowaniu ukraińskich jednostek wojskowych. W rezultacie w październiku 1917 r. Generalny Komitet Wojskowy zaczął przejmować kompetencję rosyjskich władz wojskowych na terenie Ukrainy.

Wzmocnienie wpływów Centralnej Rady w wojsku zauważyli bolszewicy, a dla nich groziło to utratą wpływów na Ukrainie. Korzystając z katastrofalnej sytuacji, w jakiej znalazło się wojsko, jak też wzrost wśród żołnierzy nastrojów antywojennych, rozwinęli potężną propagandę, rzucając populistyczne hasła uderzające swoim radykalizmem. W ciągu września i października 1917 r. wyraźnie postrzegano radykalizację nastrojów w wojsku. Agitacja bolszewicka trafiała na podatny grunt. Na razie bolszewicy otwarcie nie wypowiadali się za obaleniem Centralnej Rady; przede wszystkim ostrze ich propagandy kierowało się przeciwko Rządowi Tymczasowemu. W słowach nadał popierali prawo do samostanowienia narodów i powstania państw narodowych. Rozdmuchiwali konflikty na gruncie socjalnym, starając się wciągnąć do niego żołnierzy. W połowie października Rząd Tymczasowy i Centralna Rada widocznie traciły kontrolę nad armiami na frontach południowo-zachodnim i rumuńskim. Po załamaniu się frontów wielotysięczne tłumy przesiąkniętych ideologią bolszewicką żołnierzy ruszyły do domu, po drodze dokonując grabieży i pogromów. Pierwszy duży pogrom na Podolu w październiku 1917 r. dokonany został przez żołnierzy II Korpusu Gwar-

${ }^{67}$ Czerwona Gwardia - formacje zbrojne partii bolszewickiej; powstały w marcu $1917 \mathrm{r}$. Zgodnie z koncepcją W. Lenina miały służyć jako gwarancja „swobód i zniesienia caratu do końca". Rekrutowała się z robotników na zasadach ochotniczych. Na Ukrainie istniejące wcześniej zbrojne oddziały milicji robotniczej pod przewodem bolszewików w okresie od maja do lipca 1917 r. przekształciły się w formacje Czerwonej Gwardii. Wspierając się na nich, bolszewicy usuwali terenowe organa władzy Centralnej Rady i tworzyli własne struktury administracji. W 1918 r. Czerwona Gwardia została włączona do regularnej Armii Czerwonej. Великий Жовтень і громадянська війна на Украӥні. Енииклопедичний довідник. Ред. І.Ф. Курас, П.Л. Варгатюк, Київ 1987, s. 522-523. 
dyjskiego z działaczką bolszewicką Eugenią Bosz ${ }^{68}$ na czele. Ofiarami pogromów żołnierskich padały nie tylko dwory, folwarki, cukrownie i gorzelnie, ale i ukraińskie wsie ${ }^{69}$. Zbolszewizowane oddziały wojskowe inicjowały pogromy majątków, wciągając do tego masy chłopstwa. Pragnąc zapanować nad sytuacją w kraju i wzmocnić swoje wpływy w wojsku, 12/25 października 1917 r. Generalny Sekretariat uchwalił deklarację, w której określił swoje kompetencje i zasady polityki wewnętrznej. Dla zapobieżenia rosnącej anarchii Generalny Sekretariat zobowiązał swój resort spraw wewnętrznych do tworzenia oddziałów Wolnych Kozaków i podporządkowania ich w terenie organom samorządowym. W deklaracji Generalny Sekretariat oświadczał, że poszerza swój skład o sekretarzy resortów do spraw aprowizacji, komunikacji, poczty i telegrafu, sprawiedliwości. Dla zwalczania dezercji i uniknięcia w kraju chaosu, jaki ta niosła ze sobą, Generalny Sekretariat oświadczył, że inkorporuje do swojego składu na prawach sekretariatu Generalny Komitet Wojskowy, który upoważniono do organizowania ukraińskich formacji wojskowych, a także do obsadzenia stanowisk naczelników wojskowych na Ukrainie, szczególnie w kijowskim i odeskim okręgach wojskowych. Formalnie miał on proponować kandydatury do zatwierdzenie przez kwaterę główną.

${ }^{68}$ Eugenia Bosz (prawdziwe nazwisko Majsz), (1879-1925), działaczka partii bolszewickiej i radzieckich organów państwowych. Pochodziła z miasteczka Oczaków guberni chersońskiej na Ukrainie. Ojciec Gotlib Majsz był mechanikiem, matka pochodziła ze szlachty mołdawskiej. Po przedwczesnej śmierci ojca żyła w trudnych warunkach, uczyła się w gimnazjum. W końcu lat 90. XIX w. zbliżyła się do rosyjskiego ruchu socjaldemokratycznego, a w 1901 r. wstąpiła do RSDPR, po 1903 r. jako członek jej frakcji bolszewickiej. Od 1905 r. poświęca się wyłącznie działalności partyjnej i obejmuje kierownicze stanowiska w organach partii bolszewickiej między innymi w kijowskiej organizacji RSDPR(b). W 1912 r. została aresztowana i skazana na zesłanie do guberni irkuckiej, skąd (1914) zbiegła przez Władywostok do Ameryki. Po upadku caratu w marcu 1917 r. powróciła do Rosji. Na początku do Piotrogrodu, później do Kijowa. Tu została wybrana członkiem kijowskiego komitetu partii bolszewickiej i rady delegatów robotniczych. Od kwietnia 1917 r. stała na czele struktur obwodowych partii bolszewickiej na terenie Ukrainy. Brała czynny udział w przygotowaniu powstania przeciwko Centralnej Radzie w listopadzie - grudniu 1917 r. Po proklamowaniu w Charkowie władzy rad na Ukrainie została wybrana członkiem Centralnego Wykonawczego Komitetu radzieckiej Ukrainy i jej rządu Ludowego Sekretariatu (ludowy sekretarz spraw wewnętrznych). W czasie walk z armią URL i sprzymierzonymi wojskami austriacko-niemieckimi w lutym - marcu 1917 r. kierowała pracą polityczną w pułku Czerwonych Kozaków, jedynej formacją ukraińskiej radzieckiego rządu Ukrainy, a w 1918-1919 na innych frontach Armii Czerwonej; od 1920 r. pracowała w organach państwowych; w 1923 r. związała się z opozycją Trockiego. W ostatnich latach życia ciężko chorowała, dłuższy czas leczyła się na Kaukazie, w Niemczech i Włoszech; 5 I 1925 r., nie mogąc znieść cierpień będących skutkiem choroby, popełniła samobójstwo. Деятели СССР и революиионного движения в России. Энииклопедический словарь Гранат, Москва 1989, s. 367-368; Гражданская война и военная интервенция в СССР. Энциклопедия. Главный рудактор С.С. Хромов, Москва 1983, s. 72; Великий жовтень і громадянська війна на Україні..., s. 65.

${ }^{69}$ B. Hud, Ukraincy i Polacy na Naddnieprzu, Wolyniu i w Galicji w XIX i pierwszej połowie XX wieku. Zarys konfliktów społeczno-etnicznych, Lwów-Warszawa 2013, s. 227. 
Generalny Sekretariat oznajmił nadto, że uważa za nienormalne ograniczenie jego kompetencji do pięciu guberni Ukrainy i będzie dążył do usunięcia takiego $\operatorname{stanu}^{70}$.

W sytuacji zupełnej utraty autorytetu i wpływu na bieg wydarzeń Rządu Tymczasowego Mała Rada na sesji 10/23 - 18/31 października 1917 r. przyjęła uchwałę o zwołaniu w styczniu 1918 r. ukraińskiej konstytuanty (Wszechukraińskiego Zgromadzenia Narodowego), która miała zadecydować o przyszłym kształcie państwowości ukraińskiej. W odpowiedź na ten samowolny akt rząd rosyjski oskarżył Centralną Radę o zdradę stanu i zapowiedział wszczęcie postępowania sądowego ${ }^{71}$. Jednak do procesu nie doszło, ponieważ 25 października / 7 listopada 1917 r. Rząd Tymczasowy został obalony przez zamach bolszewicki.

\section{W PRZEDDZIEŃ NIEPODLEGŁOŚCI I NIEPODLEGŁOŚĆ}

W II Ogólnorosyjskim Zjeździe Rad (to ten, na którym w nocy 25/26 października [7/8 listopada] 1917 r. ogłoszono dokonanie zamachu stanu) wzięła udział duża grupa delegatów z Ukrainy, w tym prawie połowa to bolszewicy. Bolszewicki zamach stanu w Piotrogrodzie wywołał dalszą aktywizację bolszewików na terenie całej Ukrainy. W samym Kijowie UCR zajęła stanowisko przyjaznej neutralności wobec bolszewików w ich walce z wojskami wiernymi Rządowi Tymczasowemu i w ten sposób agendy rządowe zostały na Ukrainie zlikwidowane. Nie przyniosło to jednak zwycięstwa bolszewikom, gdyż w czasie walk Generalny Sekretariat wydał wojskom ukraińskim rozkaz obsadzenia gmachów urzędów w Kijowie. Zamach stanu i utworzenie w Piotrogrodzie rządu bolszewików - Rady Komisarty Ludowych - postawił Centralną Radę przed koniecznością zajęcia stanowiska wobec nowych władz. Centralna Rada uczyniła to nie zwlekając. Na posiedzeniu Małej Rady 26 października / 8 listopada 1917 r. przyjęto uchwałę, w której potępiono zamach bolszewicki z uzasadnieniem, że władza w państwie ma reprezentować wszystkie siły demokratyczne, a nie tylko ich część, jaką są rady robotnicze i żołnierskie, zatem wszelkie próby buntu na Ukrainie będą sthumione. 28 października /10 listopada z odezwą Do wszystkich obywateli Ukrainy zwrócił się Generalny Sekretariat. W odezwie stwierdzono, że część ludności Piotrogrodu kierowana przez bolszewików wystąpiła z bronią w ręku przeciwko Rządowi Tymczasowemu i pragnie narzucić swoją wolę Rosyjskiej Republice. Generalny Sekretariat apelował do obywateli Ukrainy o zachowanie

\footnotetext{
70 О.П. Копиленко, „Сто днів” Центральної Ради, Київ 1992, s. 172-173, 179-180.

${ }^{71}$ П. Христюк, Замітки і матеріяли до історії Украӥнської революиії 1917-1920, t. 2, Відень 1921, s. 20.
} 
spokoju i poparcie rządu. Bolszewicy na Ukrainie odebrali ten akt jako wymierzony w nich atak i zaczęli otwarcie przygotowywać się do buntu przeciwko Centralnej Radzie.

Rewolucja październikowa w Piotrogrodzie wydała na świat momentalnie Dekret o pokoju $u^{72}$, a wkrótce (2/15 listopada 1917) Deklaracje praw narodów Rosji $^{73}$. Oba te dokumenty mogły wzbudzić nadzieję dla realizacji narodowych aspiracji Ukraińców. Centralna Rada nadal trzymała się koncepcji przeobrażenia Rosji na luźną federację. Przewodniczący Centralnej Rady profesor M. Hruszewski w swojej pracy pt. Jakiej my chcemy autonomii i federacji podkreślał, że chodzi o „szeroką autonomię”, która „mniej-więcej zbliża się do państwowej niepodległości”. W innym miejscu precyzował, że ma to być „,szeroka polityczna autonomia”, a w odniesieniu do Ukrainy „narodowo-terytorialna”. Ta ostatnia „powinna załatwiać u siebie w domu różne swoje sprawy - gospodarcze, kulturalne, polityczne, utrzymywać swoje własne wojsko, rozporządzać swoimi drogami, ziemią, swoimi dochodami i bogactwami naturalnymi, mieć swoje ustawodawstwo, administrację i sądownictwo. Jedynie w określonych sprawach, wspólnych dla całego państwa rosyjskiego, Ukrainę mogą obowiązywać uchwały przedstawicielstwa państwa rosyjskiego, w którym będą brali udział reprezentanci Ukrainy proporcjonalnie do jej ludności i ludności całej republiki rosyjskiej"’74.

Upadek Rządu Tymczasowego i nasilające się procesy dezintegracji Rosji, chaos w administracji, zmusiły Centralną Radę do podjęcia wyzwania, jakie niosły wydarzenia. 1/14 listopada 1917 r. proklamowała siebie najwyższym organem władzy krajowej, a 3/16 listopada Generalny Sekretariat oficjalnie oświadczył, że bierze władzę na Ukrainie w swoje ręce i obejmuje nią cały kraj, to znaczy dziewięć guberni, w których ukraińska ludność stanowi większość. 6/19 listopada delegaci Centralnej Rady odwiedzili kwaterę główną i podpisali umowę, według której uznano za celową zasadę terytorialnej dyslokacji wojska. Oznaczało to pełną legalizację sformowanych na Ukrainie jednostek wojskowych ${ }^{75}$.

Rozpoczął się nowy etap w działalności Centralnej Rady. Wyłonienie się de facto państwa ukraińskiego potrzebowało umocowania prawnego. Toteż już

72 История советской конституции. Сборник документов. 1917-1957. Издательство Академии Наук СССР. Москва 1957, s. 9-11; История советской конституции (в документах) 1917-1956. Государственное издательство юридической литературы. Москва 1957, s. 44-47. Są publikacje w języku polskim, ostatnio m.in. [w:] Powszechna historia ustroju. Wybór źródet..., s. 494-496.

73 История советской конституичи. Сборник документов. 1917-1957..., s. 19-20; История советской конституциии (в документах) 1917-1956..., s. 57-58; Powszechna historia ustroju. Wybór źródet..., s. 498-499.

${ }_{74}$ М. Грушувський, Якої ми хочемо автономії й федерації, [w:] Хто такі українці і чого вони хочуть? ..., s. 125,126.

75 В. Голубко, Армія Украӥнської Народної Республіки..., s. 116. 
7/20 listopada 1917 r. Centralna Rada, w III Uniwersale, proklamowała powstanie Ukraińskiej Republiki Ludowej (URL) w federacyjnym związku z Rosją ${ }^{76}$.

Trzeci uniwersał zawierał też, ogólnikowe wprawdzie, ale jednak zawierał, obietnice załatwienia palących problemów społecznych, z kwestią agrarną i ośmiogodzinnym dniem pracy na czele. Po bolszewickim dekrecie o ziemi $i^{77}$ ogłoszonym w pierwszych godzinach po obaleniu Rządu Tymczasowego w Piotrogrodzie, ze sprawą reformy rolnej na Ukrainie czekać nie było już można. Pierwsze kroki już faktycznie suwerennych władz ukraińskich świadczyły o tym, że pragną zachować ciągłość władzy i dotrzymywać legalności w tworzeniu prawa. 26 listopada / 8 grudnia 1917 r. Centralna Rada uchwaliła Ustawe o porzadku wydawania nowych ustaw, stanowiąc, że do momentu powstania federacyjnej republiki rosyjskiej i uchwalenia jej konstytucji wyłączne prawo wydawania ustaw dla Ukraińskiej Republiki Ludowej należy do Centralnej Rady, zaś prawo wydawania rozporządzeń na podstawie ustaw należy do kompetencji Generalnego Sekretariatu. Jednocześnie ta ustawa kasowała wszelkie akty prawne obowiązujące do 26 listopada / 8 grudnia 1917 r. Organy administracji istniejące na Ukrainie do proklamowania URL miały kontynuować swoją działalność ${ }^{78}$.

Budowa podstaw ukraińskiej państwowości miała miejsce na tle pogłębiającego się kryzysu społecznego i ustrojowego. Najbardziej widocznie i nie bez wpływów bolszewików postępowała radykalizacja szerokich warstw społecznych, zwłaszcza żołnierskich i chłopskich. Najtrudniejszą dla Centralnej Rady pozostawała reforma agrarna. Na mocy wspomnianego bolszewickiego dekretu o ziemi miała zostać skasowana wielka własność ziemska. Ziemie uznano za

${ }^{76}$ Історія держави і права Украӥни..., t. 2 , s. 50.

${ }_{77}$ Dekret II Wszechrosyjskiego Zjazdu Rad Delegatów Robotniczych, Żołnierskich i Chłopskich o ziemi z 26 X(8 XI) 1917 r. był jednym z trzech pierwszych dekretów bolszewickich, wydanych w pierwszych godzinach po obaleniu Rządu Tymczasowego. Dekret konfiskował bez odszkodowania całą obszarniczą własność ziemską. Z konfiskaty wyłączone były jednak gospodarstwa chłopskie. Dekret o ziemi znosił na zawsze wszelką prywatną własność ziemi, lasów, bogactw naturalnych. Zakazano jakiegokolwiek obrotu ziemią. Wszechrosyjski Centralny Komitet Wykonawczy 6/19 II 1918 r. wydał dekret o socjalizacji ziemi. Dekret o socjalizacji ziemi we wszystkich istotnych sprawach powtarzał regulacje zawarte we wcześniejszym dekrecie o ziemi - w szczególności znosił na zawsze wszelką własność prywatną ziemi, zakazywał obrotu ziemią. История советской конституции (в документах) 1917-1956..., s. 113; История советской конституции. Сборник документов. 1917-1957..., s. 53; zob. N. Reich, Sozialismus und Zivilrecht. Eine rechtstheoretisch-rechtshistorische Studie zur Zivilrechtstheorie und Kodifikationspraxis im sowjetischen Gesellschafts- und Rechtssystem, Frankfurt am Main 1972, s. 87; О.С. Иоффе, [w:] Сорок лет советского права 1917-1957, t. 1: Период строительства соииализма. (ред.) М. Д. Шаргородский, t. 2: Период соииализма, (ред.) О.С. Иоффе, Ленинград 1957, t. I, s. 196. Bliżej zob. A. Lityński, Prawo Rosji i ZSRR 1917-1991 czyli historia wszechzwiązkowego komunistycznego prawa (bolszewików). Krótki kurs, wyd. 2, Warszawa 2012, s. 216 i n.

78 „Вістник Генерального Секретаріяту” 1917, Nr. 1, s. 1. 
własność ogólnonarodową. Deklarowano przekazanie jej chłopom w wieczyste użytkowanie bezpłatnie, co pchnęło ich do samorzutnych podziałów ziemi wielkich właścicieli. Centralna Rada, chcąc nadążyć za bolszewikami w III Uniwersale, również zadeklarowała przekazanie bez wykupu ziemi chłopom, lecz próbowała to zrobić w sposób cywilizowany. W tym celu przewidywała utworzenie lokalnych komitetów rolniczych. Centralna Rada zleciła Generalnemu Sekretariatowi natychmiastowe ustanowienie norm prawnych, które miałyby regulować sposób rozporządzania ziemią do czasu zwołania Ukraińskiego Zgromadzenia Ustawodawczego $^{79}$. Jednakże ten punkt Uniwersatu nie ustabilizował sytuacji. W porównaniu z rozwiązaniami bolszewików Centralna Rada traciła inicjatywę, gdyż proponowała skomplikowaną i długotrwałą procedurę podziału majątków, co nie satysfakcjonowało zrewoltowanych chłopów. Natomiast bolszewicy widzieli natychmiastowe przejęcie ziemi. Ich populistyczne idee były na tyle atrakcyjne dla chłopów, że rychło pomogły im zdobyć popularność w środowisku wiejskim. Rozpad armii carskiej, tysiące dezerterów, którzy wracali z frontu i byli pod wpływem bolszewików, jeszcze bardziej zaogniało sytuację. Żołnierze stali się głównymi organizatorami pogromów majątków wielkich właścicieli ziemskich. Na Wołyniu i Podolu w zdecydowanej większości były to majątki ziemiaństwa polskiego. To wszystko skutkowało dezorganizacją lokalnej administracji państwowej URL. III Uniwersat nie przyniósł Centralnej Radzie popularności wśród chłopów, a zepsuł relacje między jej ukraińską większością a przedstawicielami mniejszości narodowych. Wszystkie polskie organizacje wyraziły ostry sprzeciw wobec tego ,aktu krzywdy”, który niszczył „,podstawy ekonomiczne egzystencji wielkiej liczby Polaków od dawna zamieszkałych na Ukrainie"80. Na znak protestu z Centralnej Rady wystąpili Polacy; podał się do dymisji sekretarz ds. polskich Mieczysław Mickiewicz. W celu złagodzenia powstałego napięcia 15 listopada 1917 r. Generalny Sekretariat rozesłał władzom lokalnym komentarz do Uniwersalu, w którym powiatowym i wiejskim komitetom rolniczym zabroniono przejmowania i dzielenia między chłopów majątków ziemiańskich, ponieważ zostały one uznane za własność ogólnonarodową ${ }^{81}$. Komentarz naraził Centralną Radę i rząd URL na jeszcze większe nasilenie skierowanej przeciwko nim agitacji bolszewickiej i otwartego wezwania do ich obalenia jako „burżuazyjnych”. 11/14 grudnia 1917 r. chorąży Nikołaj Krylenko ${ }^{82}$, mianowany przez rząd bol-

79 Українська суспільно - політична думка в 20 столітті: Документи і матеріали. Ред. Т. Гунчак, Р. Сольчаник, t. 1, [b.m.], Сучасність 1983, s. 341.

${ }^{80}$ B. Hud, Ukraińcy i Polacy na Naddnieprzu, Wotyniu $i$ w Galicji w XIX i pierwszej połowie XX wieku..., s. 236.

${ }^{81}$ Ibidem.

${ }^{82}$ Nikołaj Krylenko (1885 - 1938), bolszewicki działacz wojskowy. Pochodził z rodziny drobnego urzędnika państwowego. W 1890-1903 mieszkał razem z rodziną w Polsce, na początku 
szewików naczelnym dowódcą, zwrócił się do ukraińskich żołnierzy z odezwą, w której oznajmił, że Rada Komisarzy Ludowych „będzie walczyć za niepodległą ukraińską republikę taką jak nasza [to znaczy jak Rosja radziecka - aut.], gdzie władza będzie w rękach rad delegatów robotniczych, żołnierskich i chłopskich"»3. Ostro zareagował na to przewodniczący Generalnego Sekretariatu W. Wynnyczenko: „Agitacja bolszewików dąży do tego, żeby uznać tylko to, co powiedzą oni, Moskale. Damy im odpowiedź: nie!"»44.

W grudniu 1917 r. konfrontacja między Rosją bolszewicką a URL sięgnęła szczytu i groziła przejściem w otwarty konflikt zbrojny. Pozostawało tylko znaleźć pretekst. Podłożem konfliktu oczywiście były sprzeczności dwóch przeciwstawnych modeli rozwoju państwowego Ukrainy i Rosji: demokratycznego, jaki pragnęła realizować Centralna Rada, i totalitarnego połączonego z ideologią imperialną, z którym występowała Rada Komisarzy Ludowych na czele z Leninem. Do zaostrzenia konfliktu mocno przyczyniła się działalność Semena Petlury, tworzącego ukraińską siłę zbrojną. Bolszewicy, nie mając szerokiego poparcia na Ukrainie, byli świadomi, że zdobyć władzę mogą wyłącznie siłą, zaś stworzenie silnego wojska ukraińskiego minimalizowało ich szanse. Ostrze swej agitacji bolszewicy zwrócili przeciwko ukraińskim formacjom wojskowym. Jednocześnie z przeciągnięciem na swoją stronę jednostek byłej armii carskiej zaczęli rozbudowywać swoje siły zbrojne w postaci Czerwonej Gwardii, będącej w gruncie rzeczy bojowymi jednostkami partii bolszewickiej. Najskuteczniej tworzono je w zrusyfikowanych regionach przemysłowych, w Donbasie, w Charkowie, Mikołajowie i innych dużych miastach. Według obliczeń historyków radzieckich ich liczebność wynosiła około 40 tys. ludzi ${ }^{85}$. Centralna Rada dostrzegała wynikające stąd niebezpieczeństwo i w połowie grudnia 1917 r. użyła swojego wojska przeciwko rozprzestrzenianiu się bolszewizmu na Ukrainie. Wojska ukraińskie rozbroiły oddziały Czerwonej Gwardii w Jekaterynosławiu, Mikołajowie, Odessie, a w Połta-

w Kielcach później w Lublinie, gdzie ukończył gimnazjum klasyczne. Ukończył studia na wydziale historyczno-filologicznym uniwersytetu petersburskiego i prawniczym uniwersytetu w Charkowie. W 1904 r. wstąpił do partii bolszewickiej. W czasie pierwszej wojny światowej zmobilizowany do armii rosyjskiej w stopniu chorążego. Brał czynny udział w zamachu bolszewickim, wybrany do pierwszego składu rządu - Rady Komisarzy Ludowych - na stanowisko komisarza ds. wojskowych i marynarki. Od listopada 1917 do marca 1918 Naczelny Dowódca sił zbrojnych Rosji radzieckiej. W marcu 1918 r. wskutek nieakceptowania polityki wojskowej Lwa Trockiego przeniesiony do komisariatu ds. prawnych; jeden z organizatorów radzieckiej prokuratury i sądownictwa, przewodniczący trybunału rewolucyjnego; brał udział w najgłośniejszych procesach politycznych. Rozstrzelany w 1938 r. w okresie represji stalinowskich. Деятели СССР и револючионного движения в России. Энциклопедический словарь Гранат, Москва 1989, s. 465-466; Гражданская война и военная интервенция в СССР. Энщиклопедия. Гл. ред. С.С. Хромов, Москва 1983, s. 307.

83 В. Голубко, Армія Української Народної Республіки 1917-1918..., s. 126.

${ }^{84}$ П. Христюк, Замітки і матеріяли до історії Украӥнської революиії 1917-1920 ..., t. 2, s. 79.

85 П.Ш. Гарчев, Червона гвардія Украӥни в боротьбі за владу Рад, Київ 1983, s. 15. 
wie, Konotopie i innych miastach rozpędziły bolszewickie rady. Do miast w pasie przyfrontowym rząd ukraiński wprowadził wojsko. Stłumiono bolszewicki bunt 1/13 grudnia 1917 r. w Kijowie, a żołnierzy bolszewickich rozbrojono i wysłano pociągami do Rosji ${ }^{86}$. Sztab powstania - Komitet Wojskowo-Rewolucyjny na czele z Leonidem Piatakowem aresztowano. Wysłana przez N. Krylenkę pomoc bolszewikom kijowskim w postaci zbolszewizowanego II korpusu gwardyjskiego nie przyniosła efektu: korpus został rozbrojony przez siły ukraińskie pod dowództwem generała P. Skoropadśkiego. Wydawało się, że Centralna Rada opanowała sytuację. Okazało się jednak, że są to tylko pozory.

Rząd Lenina był bardzo zaniepokojony rokowaniami podjętymi przez Centralną Radę i Generalny Sekretariat z innymi rządami powstałymi na terenach Rosji po zamachu bolszewickim w celu utworzenia ogólnorosyjskiego rządu federalnego, który by proporcjonalnie reprezentował wszystkie siły polityczne. Bolszewicy oczywiście straciliby wówczas władzę. Jednak prowadzone przez stronę ukraińską rozmowy nie dawały poważnych efektów. Na notę Generalnego Sekretariatu odnośnie do stworzenia rządu federalnego dał odpowiedź tylko rząd Obwodu Dońskiego pod dowództwem generała Kozaków dońskich Aleksandra Kaledina $^{87}$. W byłym imperium carów Kozacy liczyli około 4,5 mln osób, przy czym co najmniej ${ }^{88} 300$ tys. z nich walczyło w I wojnie światowej; tradycyjnie ludność kozacka trudniła się służbą wojskową. Kozacy mieli silne poczucie odrębności i wewnętrznej spójności (także między oficerami i prostymi żołnierzami). W czasach carskich na ogół cieszyli się przywilejami, m.in. mieli prawo tworzenia lokalnych samorządów. Ich najwyższą władzą samorządową był tzw. krąg wojskowy (rada wojskowa), w którym mieli prawo uczestniczyć zdolni do noszenia broni lub w tym rzemiośle mający dawne zasługi; wybierali swojego atamana; mieli sąd z obieranymi sędziami. W rezultacie byli mniej podatni na hasła rewolucyjne. W Polsce skojarzenie Kozaka łączy się powszechnie z Ukrainą i miewa rodowód Sienkiewiczowski. Trzeba jednak zdawać sobie sprawę, że Kozacy - rozmaitego zresztą pochodzenia etnicznego ${ }^{89}$ - mieli swoje siedziby od Ukrainy aż do Amuru.

${ }^{86}$ В. Верига, Визвольні змагання в Украӥні 1914-1923, t. 1, Львів 1998, s. 180.

${ }^{87}$ Aleksiej M. Kaledin (1861-1918), generał, podczas I wojny światowej dowódca korpusu i armii; w VI 1917 wybrany atamanem kozackiego Wojska Dońskiego; po klęsce w walkach z bolszewikami popełnił samobójstwo. Leksykon historii świata: Rosja ..., s. 121.

${ }^{88}$ Niektóre źródła podają liczbę 450 tys. żołnierzy kozackich w przededniu I wojny światowej. WEP XIV, s. 499.

${ }^{89}$ M.in.: Kozacy dońscy w najdalszych swoich korzeniach etnicznych pochodzą od ludów tureckich, a elementy kultury turańskiej istniały jeszcze w połowie XIX w.; Kozacy kubańscy to przybysze z Zaporoża, znad Donu, Czerkiezi; Kozacy terscy (tereccy) to w części potomkowie Kabardyńców i Osetyjczyków, Czeczenów i Inguszy; Kozacy siemireccy (siemirieczeńscy) to m.in. potomkowie zesłanych hajdamaków, konfederatów barskich oraz jeńców napoleońskich. 
Generał A. Kaledin proklamował Obwód Doński niezależnym od bolszewików terenem i wezwał Kozaków do wszczęcia walki z nimi. W ten sposób rząd URL znalazł się w niezręcznej sytuacji ponieważ przystąpił do rokowań z przeciwnikiem Rady Komisarzy Ludowych. Rząd bolszewicki zarzucał Generalnemu Sekretariatowi, że ten przystąpił do spisku antyradzieckiego z generałem A. Kaledinem, czego dowodem jest zezwolenie na przemarsz oddziałów kozackich z frontu południowo-zachodniego i rumuńskiego przez terytorium Ukrainy na wschód, do Obwódu Dońskiego i ogłosił Generalny Sekretariat organizacją wrogą wobec ludu pracującego, a więc kontrrewolucyjną. W odpowiedzi 30 listopada / 13 grudnia 1917 r. rząd ukraiński wydał oświadczenie, w którym prostował insynuacje rosyjskich bolszewików i oznajmił, że do projektowanego federalnego rządu może przystąpić również Rada Komisarzy Ludowych. Generalny Sekretariat oznajmił, że ,żadnych tajnych peretraktacji z Kozakami nie prowadzi. Prowadzone są z nimi peretraktacje odnośnie utworzenia centralnego rządu dla całej Republiki Rosyjskiej; jednocześnie takie same rokowania prowadzone są z Ludowym Sowietem w Piotrogrodzie, z rządem Syberii, z rządem Kaukazu i z rządami innych republik [...]. Tylko taki rząd, według Generalnego Sekretariatu, może decydować o bycie państwowym całej Rosji. [...] Dopóki takiego rządu nie ma, Generalny Sekretariat nie uważa za stosowne stać po stronie tego lub innego obwodu. $Z$ tego względu Generalny Sekretariat uznaje prawo Komisarzy Ludowych z Wielkorosji, jak i Kozaków nad Donem i na Kubaniu oraz na innych ziemiach decydowania o swoim życiu. Nie uważa więc za słuszne zatrzymywanie wojskowych oddziałów kozackich, gdy te chcą przejść do swojego kraju. Generalny Sekretariat podobnie uważa za niedopuszczalne zatrzymywanie jednostek rosyjskich, które wyraziły chęć przejścia do Rosji [...], niedopuszczalne jest, że Komisarze Ludowi zatrzymują oddziały ukraińskie nie przepuszczając ich na Ukrainę"90. W związku z powyższym rząd URL oficjalnie zajął pozycję neutralną w konflikcie bolszewików z Kozakami dońskimi. Jednak zachowanie neutralności okazało się niemożliwe tak z powodu sytuacji geopolitycznej Ukrainy, która znalazła się pomiędzy walczącymi w wojnie światowej stronami, jak również z powodu polityki rosyjskiego rządu bolszewików, który uzurpował sobie funkcje rządu federalnego. 3/16 grudnia 1917 r. naczelny dowódca wojsk bolszewickich N. Krylenko wydał rozkaz o zawieszeniu formowania oddziałów ukraińskich ${ }^{91}$. Następnego dnia 4/17 grudnia 1917 r. Rada Komisarzy Ludowych decyzją Lenina wysłała do Kijowa Manifest do narodu ukraińskiego z ultymatywnymi żadaniami do Ukraińskiej Rady, co w praktyce znaczyło wypowiedzenie wojny. W Manifeście bolszewicy werbalnie uznawali prawo Ukrainy do samostanowie-

\footnotetext{
90 „Вістник Генерального Секретаріяту УНР” 1917, Nr. 4, s. 1.

91 В. Голубко, Армія Української Народної Республіки..., s. 129.
} 
nia i nawet do niepodległości, ale stawiali warunki. Mianowicie żądali od strony ukraińskiej zawieszenia formowania oddziałów wojskowych pod pretekstem, że prowadzi to do dezorganizacji frontu, żądali nieprzepuszczania w kierunku Donu i Uralu oddziałów kozackich bez zezwolenia dowództwa bolszewickiego, żądali zaprzestania rozbrajania oddziałów Czerwonej Gwardii na Ukrainie i niezwłocznego zwrotu odebranej im broni, jak też żądali udzielenia bolszewikom pomocy w walce z silami kontrrewolucyjnymi nad Donem. „W razie nieotrzymania pozytywnej odpowiedzi na te pytania w ciągu 48 godzin Rada Komisarzy Ludowych będzie uważała Radę za znajdującą się w stanie otwartej wojny przeciwko władzy rad w Rosji i na Ukrainie" ${ }^{92}$. Odpowiedź rządu URL odrzucała żądania bolszewików rosyjskich, wskazywała na ich absurdalność: „Nie można jednocześnie uznawać prawa do samostanowienia aż do odłączenia się i jednocześnie brutalnie łamać to prawo, narzucać własne formy politycznego ustroju państwu, które się samookreśliło"93. Odrzucenie przez rząd ukraiński ultimatum to casus belli między URL i Rosją radziecką.

Bolszewicy, będąc niepewni swoich sił w otwartym starciu z Centralną Radą, próbowali zlikwidować ją w sposób „demokratyczny”, a mianowicie zwołać zjazd rad i na nim przeprowadzić nowe wybory Centralnej Rady. Wystąpili zatem z inicjatywą I zjazdu rad delegatów robotniczych, żołnierskich i chłopskich Ukrainy. Ordynacja wyborcza zaproponowana przez bolszewików gwarantowała im bezwzględną większość, a tym samym decydujący wpływ na kształt najwyższych organów władzy URL. Tym zamierzeniom zdecydowanie sprzeciwiły się ukraińskie partie polityczne reprezentowane w Centralnej Radzie. Widząc w tym zamach na URL, podjęto przeciwdziałania ${ }^{94}$. Do Kijowa wezwano wojsko, wydano polecenie dla organizacji wojskowych i Związku Chłopskiego, by wysłały na zjazd swoich delegatów ${ }^{95}$. W rezultacie w dniu otwarcia zjazdu 4/17 grudnia 1917 r. z 2500 delegatów, którzy przyjechali na zjazd, bolszewików reprezentowały 124 osoby i 16,3\% ogólnej liczby rad na Ukrainie (49 z 300 rad) ${ }^{96}$. Delegaci Centralnej Rady kwestionowali legalność zjazdu, ale wobec nalegania bolszewików zjazd został otwarty. Właśnie w tym czasie dotarł do Kijowa telegram z ultimatum Rady Komisarzy Ludowych wobec Centralnej Rady, co wywołało wielkie emocje. Delegaci oskarżali bolszewików o zdradę i nie dopuścili ich do

92 В.І. Ленін, Маніфест до украӥнського народу з ультимативними вимогами до Украӥнської Ради, [w:] Повне зібрання творів, t. 35, Київ 1973, s. 137-138.

93 „Летопись революции” (1925), nr 2, s. 60.

94 „Козацька думка”, 1917, 1 grudnia.

95 Е.Б. Бош, Год борьбы. Борьба за власть на Украине с апреля 1917 г. до немеикой оккупации, Киев 1990, s. 120-121.

96 В. Дорошкевич, М. Волошин, Незалежність України: нова спроба, „Літературна Україна" 1991, 3 stycznia. 
prezydium zjazdu. Zjazd wyraził wotum zaufania Centralnej Radzie, a bolszewicy opuścili zjazd i udali się do Charkowa. Miasto już było zajęte przez wojska rosyjskie, jakie Rada Komisarzy Ludowych - wbrew neutralności URL - przerzucała przez jej terytorium nad Don dla walki z Kozakami generała Kaledina. Rosjanie rozbroili stacjonujący w Charkowie pułk ukraiński i udzielili wsparcia delegatom przybyłym z Kijowa ${ }^{97}$, którzy wspólnie z delegatami zjazdu Zagłębia Doniecko-Krzyworożskiego ogłosili się I Wszechukraińskim Zjazdem Rad; reprezentowali mniej niż 1/3 rad Ukrainy (z 300 tylko 96). Nie bacząc na to, proklamowali 27 grudnia 1917 r. Ukraińską Ludową Republikę Radziecką. Warto dodać, że w wyborach do wszechrosyjskiego zgromadzenia ustawodawczego (konstytuanty) w listopadzie 1917 r. na Ukrainie bolszewicy zdobyli tylko $10 \%$ głosów, na ogół nieukraińskiej ludności.

Następnego dnia (28 grudnia 1917 r.) zjazd powołał najwyższe organy władzy radzieckiej na Ukrainie: Centralny Komitet Wykonawczy Rad jako najwyższy organ władzy ustawodawczej między zjazdami, a także rząd: Ludowy Sekretariat. Wykonując dyrektywy z Moskwy, zjazd przyjął dwie uchwały, a mianowicie, że Ukraina ma pozostać federalną częścią Rosji i drugą o rozciągnięciu mocy obowiązującej ustawodawstwa rosyjskiego na Ukrainę ${ }^{98}$. Zgodnie z postanowieniami zjazdu organami lokalnymi stały się powiatowe, miejskie, gubernialne i krajowe rady delegatów robotniczych, żołnierskich i chłopskich. Oprócz nich Ludowy Sekretariat mianował komisarzy, którzy wykonywali jego polecenia w terenie. Ponieważ bolszewicy podporządkowali sobie rady w terenie, przeto faktycznie objęli pełnię władzy. Ogromną rolę w tworzeniu lokalnej administracji na okupowanej części Ukrainy odegrał Ludowy Komisariat Spraw Wewnętrznych Rosyjskiej Socjalistycznej Federacyjnej Republiki Radzieckiej (RSFRR). Wydawał on różnego rodzaju instrukcje dotyczące zasad funkcjonowania administracji terenowej.

Następstwa zjazdu w Charkowie dla ukraińskiej państwowości były fatalne. Na Ukrainie powstał rozłam: Centralna Rada z jej Sekretariatem Generalnym oraz rząd bolszewicki, jakim był Ludowy Sekretariat. Na trudności kadrowe w obsadzeniu kierowników resortów Ludowego Sekretariatu (sekretarzy ludowych) wskazywała jedna z czołowych jego działaczek Eugenia Bosz. W swoich wspomnieniach przyznawała, że starano się sformować rząd z osób „w miarę z ukraińskimi nazwiskami" "99. Jeden z sekretarzy bolszewickiego Ludowego Sekretariatu - Grigorij Łapczyński - także zauważał obojętność sekretarzy bolszewickich dla tworzenia państwowości Ukrainy ${ }^{100}$. W bolszewickim rządzie tylko cztery osoby

97 И.В. Дубинский, Г.М. Шевчук, Червоное казачество, Киев 1987, s. 13.

98 Очерки советского административного права, Харьков 1924, s. 168.

99 Е.Б. Бош, Год борьбы ..., s. 141.

100 Г. Лапчинський, 3 перших днів Всеукраїнської Радянської влади, „Літопис революції” (1927), nr 5-6, s. 49. 
władały językiem ukraińskim; pozostali to Rosjanie i Żydzi ${ }^{101}$. Powstanie ukraińskiego radzieckiego rządu w Charkowie zręcznie wykorzystała Moskwa, uznając go za jedyną legalną reprezentację URL. Pod pretekstem „braterskiej” pomocy ukraińskiemu ludowi pracującemu bolszewicka Rosja podjęła zbrojną agresję przeciwko Ukrainie.

Powstały w Charkowie twór państwowy w postaci radzieckiej Ukrainy nie przedstawiał sobą jednolitego $\mathrm{w}$ sensie administracyjno-terytorialnym organizmu. Na zjeździe w Charkowie delegaci bolszewiccy reprezentowali tylko dwie części Ukrainy - Kijowszczyznę i Zagłębie Doniecko-Kryworożskie. Ci ostatni byli otwarcie wrogo nastawieni do tworzenia na Ukrainie jednego radzieckiego rządu i dążyli do utworzenia osobnej „Radzieckiej Republiki Donieckiej”, która obejmowałaby obwody charkowski oraz zagłębiowski i w całości należałaby do RSFRR. Tylko ze względu na potrzebę zachowania jednolitego frontu przeciwko Centralnej Radzie nie doszło do rozłamu pomiędzy nimi. Tereny obwodu odeskiego, taurydzkiego (południowa część Ukrainy z Krymem) w ogóle nie posiadały swojej reprezentacji na zjeździe. Ten ostatni jako „Radziecka Socjalistyczna Republika Taurydy" niezwłocznie przyłączył się do RSFRR ${ }^{102}$. Schemat bolszewickiego opanowywania Ukrainy stosowny będzie później w odniesieniu do innych regionów byłego imperium carskiego, zwłaszcza do krajów bałtyckich i kaukaskich.

Wybuch wojny z radziecką Rosją zastał URL nieprzygotowaną. Przede wszystkim Generalny Sekretariat nie wierzył w jej możliwość, bo uważał jednak bolszewików za rząd socjalistyczny, więc podobny do siebie, z którym nie dojdzie do zbrojnego starcia. Ponadto obrona kraju komplikowała się przez to, że był on przepełniony zanarchizowanymi jednostkami dawnej armii carskiej, która porzuciwszy front, powracała do domu. Ukraińska administracja wojskowa nie mogła opanować sytuacji, ponieważ zjawisko rozkładu oddziałów ukraińskich pod wpływem demagogii bolszewickiej nasilało się. Bolszewicy przekonywali żołnierzy ukraińskich, że walka toczy się na płaszczyźnie socjalnej i należy oczyścić Centralną Radę z elementów burżuazyjnych ${ }^{103}$. Sporo żołnierzy wierzyło temu, dezerterowało i śpieszyło do domu, żeby zdążyć na podział ziemi przewidziany III Uniwersałem. Niebagatelną rolę w osłabieniu obrony URL odegrała niedołężna polityka wojskowa Centralnej Rady. Jak już wspomniano, socjaliści ukraińscy orientowali się na federację z Rosją i liczyli na to, że o sprawach wojskowych będzie decydować rząd federalny. Oficjalnie trzymano się koncepcji zamiany stałej

101 В. Верига, Визвольні змагання в Україні 1914.-1923..., t. 1, s. 189.

102 М. Стахів, Україна проти большевиків. Нариси з історії агресії Совєтської Росії, t. 1, Тернопіль 1992, s. 25-27; zob. też Великий Жовтень і громадянська війна на Україні..., s. 385,471 .

${ }_{103}$ М. Грушевський, Новий період в історії України від 1914 до 1919, Київ 1992, s. 27. 
regularnej armii na milicję ludową. Nowe formacje wojska ukraińskiego rząd URL tworzył w czasie najazdu bolszewickiego, a to oczywiście było za późno. Zukrainizowane formacje, które powstały latem i jesienią 1917 r., faktycznie rozproszyły się. Wielkim błędem rządu URL było i to, że w czasie największego nasilenia się agresji rosyjskich bolszewików 4/17 stycznia 1918 r. nowy generalny sekretarz ds. wojskowych Mykoła Porzs wydał rozkaz o niezwłocznej demobilizacji zukrainizowanych, a to wobec decyzji o tworzeniu jednostek typu milicyjnego. Mianowicie dzień wcześniej (3/16 stycznia 1918) Centralna Rada przyjęła Ustawę o utworzeniu ukraińskiego wojska ludowego ${ }^{104}$. Przystąpiono do tworzenia jednostek na zasadzie terytorialnej oraz zaciągu ochotniczego, zaś trzon wojska miała stanowić kadra instruktorów, czyli zawodowych oficerów prowadzących szkolenie poborowych; instruktorzy podlegali bezpośrednio Sekretariatowi Wojskowemu. Były to działania mocno spóźnione. W połowie stycznia $1918 \mathrm{r}$. inicjatywa w działaniach wojennych przeszła w ręce bolszewickie ${ }^{105}$; ich wojska zajęły szereg miast na Ukrainie lewobrzeżnej, opanowali Zagłębie Donieckie. Niespokojnie było w Kijowie i innych miastach na tyłach. Zrusyfikowane miasta, zwłaszcza duże centra przemysłowe $\mathrm{z}$ wielotysięcznymi rzeszami proletariatu, tworzyły dobre warunki dla antyukraińskiej agitacji, przede wszystkim bolszewickiej, ale nie tylko. Partia bolszewicka nadal organizowała tam formacje Czerwonej Gwardii, a ta paraliżowała działalność lokalnej administracji URL. Jednocześnie wojska rosyjskich bolszewików posuwały się w głąb kraju, grożąc Kijowowi z północy, południowego wschodu i zachodu. Najbardziej niebezpieczna dla Ukraińców sytuacja wytworzyła się na Ukrainie lewobrzeżnej, gdzie wojska bolszewickie liczyły około 16 tys., a ukraińskie tylko 3 tys. ludzi ${ }^{106}$. Część oddziałów dowództwo ukraińskie pozostawiło w Kijowie dla ochrony najwyższych władz republiki, ponieważ obawiano się bolszewickiej rewolty; ogółem miasto broniło około 5 tys. żołnierzy ukraińskich $^{107}$. W połowie stycznia 1918 r. wojna między Rosją radziecką a URL sięgnęła szczytu. Skłoniło to przywódców Centralnej Rady do radykalnej zmiany dotychczasowej koncepcji budowania państwa, bowiem stawało się oczywiste, że plany federacyjne załamały się.

W swoim czwartym Uniwersale z 9/22 stycznia 1918 r. Centralna Rada proklamowała Ukraińską Republikę Ludową niezależnym i suwerennym pań-

104 Центральний державний архів вищих органів влади України, ф. 176 (Генеральне Секретарство по справах військових), оп. 1, спр. 6, s. 6.

105 В. Голубко, Армія Украӥнської Народної Республіки 1917-1918..., s. 159-171; zob. też A. Chojnowski, Ukraina, Warszawa 1997, s. 33-35.

106 О. Удовиченко, Україна у війні за державність. Історія організаиії бойових дій Українських Збройних Сил. 1917-1921, Київ 1995, s. 17.

${ }^{107}$ Ibidem, s. 24. 
stwem $^{108}$. Odbiło się to na składzie rządu. Od tej chwili Generalny Sekretariat przemianowano na Radę Ludowych Ministrów, a premierem w miejsce W. Wynnyczenki mianowano Wsewołoda Hołubowycza. Zmiana nazwy rządu nie była przypadkowa. Było to odzwierciedlenie konkurencji Centralnej Rady i bolszewików w przeciąganiu na swoją stronę zdezorientowanej ludności. Agitatorzy bolszewiccy w swojej demagogii posunęli się tak daleko, że nazwę Generalnego Sekretariatu wywodzili od generałów jakoby w nim zasiadających. Ustawy przyjęte przez Centralną Radę niezwłocznie po proklamowaniu niepodległości swoim radykalizmem nie bardzo różniły się od bolszewickich. Niemniej jednak w nocy z 16 na 17 stycznia (27/28 stycznia) 1918 r. bolszewicy wszczęli w Kijowie powstanie przeciw władzom ukraińskim. Miało to ułatwić ofensywę zbliżającym się ze wschodu wojskom rosyjskim pod dowództwem Michaiła Murawjowa ${ }^{109}$. Zaczęły się zacięte walki uliczne. Część byłych ukrainizowanych formacji zajęła stanowisko neutralne lub przeszła na stronę bolszewików. Oficerowie byłej armii carskiej, których było w Kijowie około 15 tys., także zachowywali przychylną neutralność wobec bolszewików ${ }^{110}$. Z mniejszości narodowych tylko Polacy wzięli udział $\mathrm{w}$ walce $\mathrm{z}$ bolszewikami po stronie ukraińskiej ${ }^{111}$.

Utrzymanie stolicy miało dla rządu ukraińskiego znaczenie najwyższej wagi, ponieważ w tym czasie delegacja URL kończyła rokowania pokojowe w Brześciu Litewskim z państwami centralnymi. Ukraina jako niepodległe państwo po kilkuset latach niewoli wkraczała na arenę międzynarodową.

108 Iсторія держави і права Украӥни..., t. 2 , s. 50; zob. też W. Serczyk, Historia Ukrainy..., s. 260; też E. Toczek, wstęp [do]: Konstytucja Ukrainy uchwalona na piatej sesji Rady Najwyższej Ukrainy 28 czerwca 1996 roku, wstęp i thumaczenie E. Toczek, Warszawa 1999, s. 7.

109 Michaił Murawjow (1880-1918), rosyjski bolszewicki działacz wojskowy, pochodził z rodziny chłopskiej, uczył się w seminarium nauczycielskim, po czym w dwuletniej szkole junkrów; za zabójstwo kolegi skazany na półtora roku służby w jednostce karnnej i zdegradowany; brał udział w wojnie rosyjsko-japońskiej i pierwszej wojnie światowej, odzyskał stopień oficerski; ciężko ranny. W 1917 r. wstąpił do partii socjalistów-rewolucjonistów. Za czasów Rządu Tymczasowego awansowany na podpułkownika. Po zamachu bolszewickim wziął aktywny udział w tworzeniu oddziałów Czerwonej Gwardii; w I-II 1918 dowodził grupą rosyjskich wojsk radzieckich na Ukrainie; w czasie szturmu Kijowa 22-26 I (4-8 II) 1918 r. wydał rozkaz użycia gazów trujących, a także ostrzału miasta z ciężkiej artylerii; żołnierze Murawjowa dopuszczali się zbrodni wobec mieszkańców stolicy Ukrainy, ofiarami padło około 5 tys. osób, między nimi zamordowano metropolitę kijowskiego Wołodymyra; w czerwcu 1918 r. dowodził wschodnim frontem. Podczas nieudanego buntu lewicowych eserowców w lipcu 1918 r. popełnił samobójstwo w Symbirsku. B. А. Савченко, Двенадиать войн за Украину, Харьков 2006, s. 52-53; zob. też М. Стахів, Україна протии большевиків..., t. 1, s. 87-88; В. Верига, Визвольні змагання в Україні 1914-1923 ..., t. 1, s. 242.

110 О. Удовиченко, Україна у війні за державність. Історія організаиії бойових дій Українських Збройних Сил. 1917-1921..., s. 14.

111 Д. Дорошенко, Мої спомини про недавне минуле (1914-1920 рр.), Київ 2007, s. 217; zob. też В. Петрів, Військово-історичні праиі. Спомини, Київ 2002, s. 319. 


\section{UKRAINA I POKÓJ BRZESKI: SUKCES I KLĘSKA}

Jako podmiot prawa międzynarodowego Ukraina pojawiła się na arenie międzynarodowej w końcowej fazie I wojny światowej. W konflikcie mocarstw Ukraina znalazła się w epicentrum pomiędzy dwoma blokami walczących w Europie państw - Ententą i państwami centralnymi, ale także wśród sąsiadów mających własne interesy w tym regionie. Realia wymagały od URL na przełomie 1917 i 1918 r. niezwłocznych i zdecydowanych przedsięwzięć. Ukraińskie dowództwo wojskowe już pod koniec 1917 r. przekonane było o konieczności zawieszenia działań wojennych na froncie niemiecko-austriackim. Po rozpoczęciu (4/17 grudnia 1917) wojny z Rosją radziecką dla URL powstało się niebezpieczeństwo wtargnięcia wojsk bolszewickich ze wschodu i okupacji kraju. Ale oprócz względów wojskowych wskazujących na celowość zawieszenia broni, wpływ miały też motywy polityczne: w toku separatystycznych rokowań brzeskich rosyjski rząd bolszewików zamierzał podpisać układ pokojowy z Niemcami i Austro-Węgrami w imieniu URL.

Jak wiadomo, w konsekwencji wspomnianego uprzednio bolszewickiego dekretu o pokoju w listopadzie 1917 r. Rada Komisarzy Ludowych podjęła aktywne starania w kierunku nawiązania rozmów pokojowych i 14/27 listopada otrzymała od Niemiec pozytywną odpowiedź odnośnie ich rozpoczęcia, a już 21 listopada /4 grudnia 1917 r. została zawarta umowa o tymczasowym zawieszeniu działań wojennych z Niemcami na rosyjskim froncie zachodnim. 9/22 grudnia 1917 r. rozpoczęły się rokowania w Brześciu Litewskim w sprawie podpisania separatystycznego pokoju pomiędzy RSFRR a państwami centralnymi ${ }^{112}$. Rząd bolszewicki przejął inicjatywę w rozpoczęciu rokowań pokojowych, czego strona ukraińska nie mogła lekceważyć, a to ze względu na antywojenne nastroje w wojsku, a przede wszystkim niemożność samodzielnego prowadzenia wojny z państwami centralnymi. Po raz pierwszy Centralna Rada wyraziła swój zamiar uczestniczenia w rokowaniach pokojowych w III Uniwersale z 7/20 listopada 1917 r. Tego samego dnia, kiedy została zawarta umowa między Rosją a Niemcami o tymczasowym zawieszeniu broni, 21 listopada / 4 grudnia 1917 r. Centralna Rada uchwaliła rezolucję o tymczasowym zawieszeniu broni na froncie południowo-zachodnim i rumuńskim oraz oświadczyła, że będzie koordynować swoje działania z Radą Komisarzy Ludowych ${ }^{113}$. Ponieważ między radziecką Rosją, Niemcami i Austro-Węgrami już była zawarta umowa o zawieszeniu broni i zostały rozpoczęte rokowania pokojowe, rządowi URL nie pozostawało nic innego jak pójść śladem bol-

112 История внешней политики СССР 1917-1985. Под. ред. А.А. Громыко, Б. Н. Пономарева. Т. 1. Москва 1986, s. 512.

113 „Козацька думка”, 1917, 26 listopada. 
szewików. W swojej odezwie Do wojska ukraińskiego z 4/17 grudnia 1917 r. rząd URL zawiadamiał, że „od tego dnia bierze sprawę rozejmu w swoje ręce i będzie ją prowadził w stanowczy sposób"114. 11/12 grudnia rząd ukraiński wystosował do państw walczących i neutralnych notę, w której informował o swojej chęci wzięcia udział $\mathrm{w}$ podpisaniu układu pokojowego jako samodzielna strona ${ }^{115}$. W dwa dni później, czyli 13/26 grudnia 1917 r., nadeszła odpowiedź państw centralnych, w której wyrażały one zgodę na przyjazd do Brześcia pełnomocników URL, co de facto znaczyło uznanie URL.

Zagadnienia dotyczące przyszłego układu pokojowego omawiała Centralna Rada na sesji od 12/25 grudnia 1917 r. Właśnie wówczas nastąpił punkt zwrotny w polityce zagranicznej ukraińskich elit rządzących. Formalnie URL jako jedna ze spadkobierczyń byłego cesarstwa rosyjskiego po jego upadku znajdowała się w bloku państw Ententy, a więc winna była kontynuować wojnę, ale przecież tego ciężaru unieść nie mogła. W czasie burzliwej dyskusji na wspomnianej sesji Centralnej Rady niejednokrotnie padało pytanie czy zmiana polityki zagranicznej nie będzie zdradą aliantów. W końcu większość pogodziła się z myślą o rozpoczęciu pertraktacji pokojowych z Niemcami i Austro-Węgrami.

W styczniu $1918 \mathrm{r}$. sytuacja militarna URL na tyle pogorszyła się, że u jej przywódców nie było już wątpliwości w sprawie konieczności niezwłocznego podpisania pokoju. Jak wspominał ówczesny komendant załogi Kijowa generał Aleksander Hrekow ${ }^{116}$, w czasie obrad w gabinecie przewodniczącego Centralnej Rady M. Hruszewskiego dyskutowano o sytuacji militarnej URL. „Hruszewski przygnębiony zbliżającą się katastrofą w dłuższym przemówieniu bardzo zasadniczo i stanowczo wypowiedział się, że w zaistniałych warunkach [...] nie ma żadnej możliwości uratowania się własnymi siłami, więc trzeba szukać potężnego sojusznika, który miałby interes nam pomóc. Było oczywiste, że miał na myśli Niemcy, jednak otwarcie ich nie wymienił"117. Uczestnicy obrad początkowo się

114 „Вістник Генерального Секретаріяту УНР” 1917, Nr. 4.

115 П. Христюк, Замітки і матеріяли..., t. 2, s. 96.

116 Aleksander Hrekow (1875-1959) generał armii carskiej, od 1917 ukraińskiej; skończył studia na uniwersytecie moskiewskim, absolwent Akademii Sztabu Generalnego; brał udział w pierwszej wojnie światowej jako dowódca róznych jednostek wojskowych; za czasów Centralnej Rady szef sztabu kijowskiego okręgu wojskowego i zastępca ministra spraw wojskowych; w 1918 hetman P. Skoropadśki mianował go naczelnikiem Sztabu Głównego Państwa Ukraińskiego; po obaleniu reżimu P. Skoropadśkiego zajmował wysokie stanowiska w Armii URL, lecz ze względów politycznych został z nich usunięty; w czerwcu 1919 mianowany Naczelnym Wodzem Ukraińskiej Armii Halickiej, którą dowodził w czasie ofensywy na froncie ukraińsko-polskim we Wschodniej Galicji; w lipcu 1919 na życzenie S. Petlury usunięty ze stanowiska wyemigrował do Wiednia; w 1948 aresztowany przez radziecki kontrwywiad wojskowy i wywieziony do Kijowa; skazany na dwadzieścia pięć lat więzienia; w 1956 zwolniony wyjechał do Austrii; zmarł we Wiedniu.

117 О. Греків, Весна 1918 року в Украӥні, [w:] „За державність”, t. 8, Торонто 1964, s. 24; Я. Тинченко, Офіиерський корпус Армї Української Народної Республіки (1917-1921), 
z tym nie zgadzali, ale ze względu na krytyczną dla URL sytuację na froncie zdecydowali się na zawarcie pokoju separatystycznego z państwami centralnymi.

Jak już wspomniano, po rozpoczęciu działań wojennych między Rosją radziecką a URL powstało niebezpieczeństwo inwazji rosyjskiej ze wschodu i dowództwo ukraińskie przystąpiło do przerzucania oddziałów z prawobrzeżnej Ukrainy na lewobrzeżną, a więc tym pilniej należało zawrzeć pokój z Niemcami i Austro-Węgrami. 19 grudnia 1917 r. (2 stycznia 1918 r.) Centralna Rada wysłała do Brześcia pierwszą delegację pod przewodnictwem W. Hołubowycza, a 28 grudnia 1917 r. (10 stycznia 1918 r.) rozpoczęły się bezpośrednie rokowania w sprawie układu pokojowego. Tymczasem sytuacja militarna URL pogarszała się z dnia na dzień. Bolszewicy rosyjscy, chociaż uznali prawo delegacji Centralnej Rady jako samodzielnej strony do prowadzenia pertraktacji, pragnęli nie dopuścić do podpisania z nią separatystycznego pokoju. Po przerwie, 16/29 stycznia 1918 r. rokowania zostały wznowione. Centralna Rada wysłała drugą delegację pod przewodnictwem Aleksandra Sewriuka, zaś delegacja rosyjska na czele z Lwem Trockim przywiozła do Brześcia delegację bolszewickiego Ludowego Sekretariatu z Charkowa i zakwestionowała pełnomocnictwa delegacji Centralnej Rady, powołując się na to, że ta utraciła Kijów i że miasto zajęły wojska bolszewickie. W celu udowodnienia kłamliwości tych insynuacji część delegacji URL powróciła do Kijowa; wówczas stolica Ukrainy była już ostrzeliwana przez artylerię bolszewicką. Rząd URL dokładał olbrzymich wysiłków, aby utrzymać się w mieście do chwili zawarcia pokoju. Zaopatrzona w instrukcję odnośnie do treści przyszłego układu pokojowego delegacja 20 stycznia / 2 lutego 1918 r. powróciła do Brześcia. W nocy na 27 stycznia / 9 lutego 1918 r., to znaczy w kilka godzin po zdobyciu Kijowa przez wojska rosyjskie, delegacja URL zdążyła podpisać traktat pokojowy z państwami centralnymi. Stanowił on zawieszenie wojny, wzajemną rezygnację z aneksji i kontrybucji, wymianę jeńców wojennych, wycofanie wojsk z okupowanych terenów, nawiązanie stosunków gospodarczych. Najważniejszą częścią traktatu brzeskiego była kwestia granic. Granicę URL z Austro-Węgrami wyznaczono według dawnej granicy rosyjsko-austriackiej sprzed 1914 r. ${ }^{118}$ Korzystając $\mathrm{z}$ katastrofalnej sytuacji żywnościowej Austro-Węgier i ich rozbieżności stanowisk z Niemcami w kwestii polskiej, ukraińska delegacja w Brześciu Litewskim wymogła włączenie do URL terenów Chełmszczyzny i Podlasia. Przyłączenie do URL tych terenów powiększało jej ludność o $3 \mathrm{mln}$ osób ${ }^{119}$. Dodatkową umową tajną przewidziano

\footnotetext{
t. 1, Київ 2007, s. 118-119; zob. też: О, Колянчук, М. Литвин, К. Науменко, Генералітет Украйнських визвольних змагань. Біограми генералів та адміралів украӥнських військових формиій першої половини ХХ століття, Львів 1995, s. 59-61.

118 Берестейський мир, Львів-Київ 1928, s. 305-307.

119 В. Верига, Визвольні змагання в Україні 1914-1923 рр..., t. 1, s. 245.
} 
przyłączenie do Galicji Wschodniej ukraińskiej części Bukowiny i utworzenia kraju koronnego jako jednostki autonomicznej monarchii austro-węgierskiej ${ }^{120}$. Niemcy i Austro-Węgry uzyskali od strony ukraińskiej zobowiązanie dostarczenia do 1 lipca 1918 r. miliona ton zboża i innej żywności. Takie zobowiązanie na piśmie Niemcy i Austro-Węgry otrzymały od Aleksandra Sewriuka i Mikołaja Lewitskiego ${ }^{121}$.

W chwili podpisywania traktatu rząd URL faktycznie nie panował już nad większą częścią kraju. 31 stycznia / 12 lutego 1918 r. delegacja URL w Brześciu za zgodą Centralnej Rady wystosowała do stron niemieckiej i austriackiej memorandum, w którym zawiadamiała o agresji Rosji bolszewickiej przeciwko Ukrainie i wzywała do przyjścia z pomocą w walce z najeźdźcą ${ }^{122}$. Młodej dyplomacji ukraińskiej w ówczesnej beznadziejnej sytuacji udało się w Brześciu osiągnąć sukces. Jednak powstaje pytanie, czy URL była w stanie skorzystać z traktatu. Odpowiedź na to pytanie daje W. Wynnyczenko: „Jednym słowem pokój ten byłby bardzo korzystny dla państwa ukraińskiego i jego rządu [...] pod jednym warunkiem: gdyby ten pokój był nie wynikiem zbiegu pomyślnych okoliczności, a wynikiem naszej siły i chęci, gdybyśmy sami mogliśmy zrealizować, obronić, ochronić i umocnić dla siebie wszystkie skutki pokoju. Wtedy na pewno byłby to pokój prawdziwy i korzystny"123.

Niemcy i Austro-Węgry wyraziły zgodę na udzielenie URL pomocy wojskowej. Niemcy oprócz bezpośredniej pomocy zbrojnej godziły się dać URL pożyczkę w wysokości 1 mld marek i wyekwipować dwie dywizje ukraińskie sformowane z jeńców ukraińskich byłej armii carskiej w Niemczech ${ }^{124}$. Konwencja wojskowa pomiędzy URL a Niemcami i Austro-Węgrami, oficjalnie podpisana 18 lutego 1918 r., stała podstawą prawną wkroczenia wojsk niemiecko-austriackich na tereny URL ${ }^{125}$.

Podpisanie separatystycznego pokoju brzeskiego spowodowało poważne korekty w sytuacji geopolitycznej w Europie. Między innymi odbiło się to na Ukrainie, która po raz pierwszy przebiła nie tylko blokadę dyplomatyczną, ale również informacyjną na arenie międzynarodowej. Natomiast Niemcy tym układem zadali dotkliwy cios swemu dawnemu konkurentowi na wschodzie Europy - Rosji. Ta straciła 26\% obszarów rolniczych, 26\% linii kolejowych, 33\% prze-

120 Берестейський мир..., s. 318-319.

121 Z. Podleski, Układy pokojowe w Brześciu Litewskim, Żelibory 1933, s. 91.

122 О. Доценко, Визвольні змагання 1917-1923. Армія, [w:] Украӥнська загальна енциклопедія, t. 3, Львів-Станіславів-Коломия 1935, s. 694.

123 В. Винниченко, Відродження начіï, t, II, Київ 1990, s. 289.

124 I. Нагаєвський, Історія Української держави двадияятого століття, Київ 1993, s. 108.

125 М. Стахів, Україна проти большевиків. Нариси з історії агресї Совєтської Росії..., t. 1, s. 52 . 
mysłu włókienniczego, $73 \%$ hutnictwa i $75 \%$ wydobycia węgla ${ }^{126}$. Secesja Ukrainy od Rosji stwarzała Niemcom warunki dla zrealizowania dawnych aspiracji geopolitycznych: przedarcia się na Kaukaz, a stamtąd do Zatoki Perskiej i Indii ${ }^{127}$, czyli zadania ciosu Wielkiej Brytanii. „Taki manewr niemiecki - pisał generał armii URL Aleksander Udowyczenko - byłby bardzo dotkliwy dla Ententy, ponieważ groziło to jej interesom na Bliskim Wschodzie i wschodzie basenu Morza Śródziemnego" $" 128$. To oczywiste.

Pokój z Ukrainą budził nadzieję w dowództwach niemieckim i austro-węgierskim zaktywizowania działań wojennych na froncie zachodnim. Nie oczekując formalnego zawarcia pokoju, Niemcy już w połowie grudnia 1917 r. zaczęli przerzucać wojska na zachód, żeby zaatakować wojska Ententy przed przybyciem wojsk amerykańskich do Europy ${ }^{129}$. Niezwłocznie po podpisaniu pokoju, w ciągu marca-lipca 1918 r., armia niemiecka kilkakrotnie przechodziła do ofensywy na froncie zachodnim. 5 lutego 1918 r., właśnie kiedy to w Brześciu Litewskim definitywnie zapadła decyzja o podpisaniu pokoju między państwami centralnymi z Ukrainą, marszałek niemiecki A. Makenzen zażądał od Rumunii, jedynego na ten czas sojusznika Ententy na wschodzie Europy, przystąpienia do rokowań pokojowych ${ }^{130}$. Mimo starań Ententy, po wkroczeniu na teren Ukrainy wojsk niemiecko-austriackich Rumunia znalazła się w kleszczach państw centralnych, a w konsekwencji skapitulowała 7 maja $1918 \mathrm{r}$.

Pokój brzeski co najmniej na pół roku odsunął katastrofę głodową Niemiec, a zwłaszcza Austro-Węgier. W swym dzienniku austro-więgierski minister spraw zagranicznych Ottokar Czernin 16 stycznia 1918 r. zanotował: „Rozpaczliwe wołania o pomoc z Wiednia. Byłem zmuszony natychmiast zwrócić się o pomoc do Berlina, ponieważ jesteśmy o krok od katastrofy"131. Jednak Niemcy mogli udzielić pomocy swojemu sojusznikowi tylko na kilka tygodni, sami bowiem odczuwali brak żywności wskutek zorganizowanej przez Ententę blokady. W tej sytuacji jedyną realną możliwością uniknięcia głodu wydawał się układ pokojowy z URL. Można więc zgodzić się z Czerninem, że „nie moglibyśmy bez dostaw ukraińskiej żywności dotrwać do nowych zbiorów. Według obliczeń, wiosną i latem 1918 r. dostarczono do nas

126 I. Нагаєвський, Історія Украӥнської держави двадиятого століття..., с. 246.

127 І.М. Кулінич Украӥна в загарбницьких планах німецького імперіалізму (1900-1914), Київ 1963, s. 56.

128 О.І. Удовиченко Україна у війні за державність..., s. 29.

129 Ч. Мессенджер, Энциклопедия войн ХХ века, Москва 2000, s. 61.

130 Краткая история Румынии. С древнейших времен до наших дней, Москва 1987, s. 303.

131 Брест-Литовск (Из мемуаров Оттокара Чернина) [w:] Архив Русской революции, t. 2, Москва 1991, s. 124. 
z Ukrainy 42 tys. wagonów żywności. Nie sposób było otrzymać tej żywności skądinąd" 132 .

Z powyższego wynika, że Ukraina stała się sprzymierzeńcem państw centralnych przeciw Entencie. To ostatnie otwierało przed nią smutną perspektywę, ponieważ po przystąpieniu Stanów Zjednoczonych do wojny po stronie Ententy można było się spodziewać, że Ukraina podzieli losy państw zwyciężonych. Podpisanie przez URL w Brześciu Litewskim traktatu z państwami centralnymi - paradoksalnie - zapoczątkowało blokadę dyplomatyczną młodego państwa. Stało się to ostro odczuwane jesienią 1918 r. i miało fatalne skutki na arenie międzynarodowej. Już 12 lutego 1918 r. generał J. Tabouis, przewodniczący francuskiej misji wojskowej na Ukrainie, jednocześnie mianowany pełnomocnym komisarzem rządu Republiki Francuskiej w Kijowie, wysłał do misji Ententy w Jassach telegram, w którym donosił, że utrzymywanie reprezentanta Francji w Kijowie jest zbędne. Na podobnym stanowisku stała też Wielka Brytania ${ }^{133}$. Niezwłocznie więc po klęsce państw centralnych w listopadzie $1918 \mathrm{r}$. Ententa otwarcie wypowiedziała się przeciwko URL tak na płaszczyźnie wojskowej, jak i dyplomatycznej. Sukces dyplomatyczny URL w Brześciu Litewskim obrócił się dla niej w katastrofę wojskową i polityczną w 1919 r., kiedy kraj znalazł się w całkowitej izolacji międzynarodowej, bez jakiejkolwiek nadziei na pomoc z zewnątrz, a nawet na przyjazną neutralność. Podsumowując skutki wojskowo-polityczne traktatu brzeskiego dla Ukrainy, Symon Petlura w 1922 r. w liście do generała armii URL Mykoły Udowyczenki pisał: „My do chwili obecnej pokutujemy za ten błąd, bo alianci do dziś nie zapomnieli nam «zdrady» naszej"134. Dzięki podpisaniu traktatu w Brześciu Litewskim URL uniknęła w 1918 r. okupacji bolszewickiej, znalazła się jednak pod surową kontrolą nowych sprzymierzeńców, którzy skierowali na jej tereny 450-tysięczny kontyngent wojskowy ${ }^{135}$.

Osobnym, lecz ważnym zagadnieniem w świetle skutków traktatu brzeskiego jest jego rzutowanie na stosunki polsko-ukraińskie. Minister spraw zagranicznych Austro-Węgier O. Czernin we wspomnieniach kilkakrotnie zwracał uwagę na to, że przyjęcie przez Wiedeń w czasie rokowań roszczeń strony ukraińskiej wobec uznania Galicji Wschodniej i Bukowiny za osobny kraj koronny z administracją ukraińską narażało monarchię na utratę ,polskich sympatii”. Na konferencji u cesarza Karola I w przeddzień podpisania traktatu w Brześciu minister usiłował udowodnić, że w imię ratunku monarchii od grożącej katastrofy głodowej należy przyjąć warunki stawiane przez delegację Centralnej Rady, jednak ze swej strony

132 Ibidem, s. 131.

133 І. Нагаєвський, Історія Украӥнської держави двадиятого століття..., s. 105.

134 С. Петлюра, Лист до генерала-хорунжсого Миколи Удовиченка, [w:] Симон Петлюра, Статті, Київ 1993, s. 223.

${ }^{135}$ Історія Української РСР: у 8 т., 10-ти кн., t. 5, Київ 1977, s. 281. 
dla złagodzenia stosunków z Polakami należy domagać się od URL gwarancji dla ludności polskiej na Ukrainie ${ }^{136}$. Kończąc dyskusję, cesarz potwierdził, że „z Ukrainą trzeba prowadzić rokowania na gruncie podziału Galicji”"137. Co się tyczy kwestii polskiej - realizacji ,aktu dwóch cesarzy” z 5 listopada 1916 r. to w Brześciu wcale jej nie poruszono. Jak widać, pokój brzeski pchnął Wiedeń do konfrontacji z Polakami, z którymi utrzymanie dobrych relacji zawsze sobie ceniono.

Jak się można było spodziewać, podpisanie traktatu pokojowego URL z państwami centralnymi wywołało nad wyraz burzliwą reakcję w polskich środowiskach. Eskalacja nastąpiła po przypadkowym ujawnieniu tajnego protokołu odnośnie do Galicji Wschodniej. Protesty były zarówno bardzo silne, jak i powszechne ${ }^{138}$. Ze względu na ostre polskie protesty, Austro-Węgry odmówiły ratyfikacji traktatu brzeskiego i w konsekwencji wycofały się z ustaleń tajnego protokołu. Oprócz Polski wrogo przyjęła traktat brzeski URL z państwami centralnymi Czechosłowacja.

Traktat brzeski między URL i państwami centralnymi był jej sukcesem taktycznym, ale jednocześnie porażką strategiczną. Skazywał młode państwo nie tylko na izolację międzynarodową, ale narażał na konflikt z zachodnimi sąsiadami. Traktat brzeski zamyka pierwszy rok historii rewolucji na Ukrainie. Dla Ukrainy był to rok odrodzenia się narodowego i państwowego.

\section{FROM THE ASHES OF THE EMPIRE. UKRAINE AFTER THE DOWNFALL OF THE RUSSIAN EMPIRE: FROM THE FEBRUARY REVOLUTION IN 1917 TO THE TREATY OF BREST-LITOVSK IN 1918}

\section{Summary}

Revolution of 1917 in the Russian Empire took place in February (according to the Julian calendar) or in March (according to the Georgian calendar used in Western Europe). As a result, Tsar Nicholas II of Russia abdicated in the first phase of the revolution which caused the fall of the Romanov dynasty. Consequently, the Provisional Government was brought into power. At the time, the First World War was ongoing and Russia suffered severe defeats in the conflict. The country was ruled by chaos and various political groups were fighting against each other. Furthermore, many nations started their fight for independence from the Russian Empire. The most significant events took place in Ukraine.

136 Брест-Литовск ( Из мемуаров Оттокара Чернина) [w:] Архив Русской революции, t. 2 , s. 127.

137 Ibidem, s. 128.

138 Zob. bliżej J. Pajewski, Odbudowa państwa polskiego 1914-1918, Warszawa 1985, s. $233-239$. 
The national activists set up their own governmental authority - Central Council of Ukraine. And, at the same time, various domestic conflicts took place in Ukraine as well. The situation was very complicated then as a 600 kilometer-long front line ran across Ukraine. Moreover, most of the country was occupied by German and Austria-Hungarian armies.

It is common knowledge that the Bolsheviks led their forces against the Provisional Government in Petrograd, which was the contemporary capital of Russia (modern-day Saint Petersburg), in October / November 1917. The Bolsheviks seized power in Russia and, in consequence, the Russian Civil War started.

The Bolsheviks were in no position to continue fighting in World War I and so they signed a separate peace treaty with Germany and Austria-Hungary in March 1918 in order to focus on the Russian Civil War. Ukraine, which was independent at the time, also signed a separate peace treaty with Germany and Austria-Hungary. A new phase in the war between Russia and Ukraine started which Ukraine eventually lost.

\section{SUR LES RUINES DE L'EMPIRE. L'UKRAINE APRES L'EFFONDREMENT DE L'EMPIRE RUSSE: DE LA REVOLUTION DE FEVRIER 1917 AU TRAITE DE BREST-LITOVSK EN 1918}

\section{Résumé}

La révolution a éclaté en Russie en février (selon le calendrier julien) ou en mars (selon le calendrier grégorien utilisé en Europe de l'Est) en 1917. En conséquence, dans la première phase de la révolution, l'empereur Nicolas II a abdiqué, ce qui a conduit à la chute de la dynastie Romanov. Le Gouvernement provisoire a commencé à exercer le pouvoir. Pendant que ces événements se déroulaient, la Première Guerre mondiale durait et la Russie a subi une défaite sévère dans le conflit. Le chaos régnait dans le pays, et de nombreux groupes politiques se combattaient mutuellement.

En outre, de nombreuses nations ont alors commencé à se battre pour son indépendance de l'Empire russe. Les événements les plus importants ont eu lieu en Ukraine. Les militants ont formé leur propre autorité d'État sous la forme du Conseil central ukrainien. En même temps, il y avait aussi lieu de divers conflits internes en Ukraine elle-même. La situation dans le pays était très compliquée parce que la ligne de front passait par l'Ukraine et mesurait $600 \mathrm{kms}$ de longueur, et la plupart du pays était occupé par les armées allemande et austro-hongroise.

Il est bien connu qu'à la fin d'octobre et au début de novembre 1917, les commandants bolcheviques ont conduit leurs troupes contre le Gouvernement provisoire à Pétersbourg, qui était alors capitale de la Russie (aujourd'hui Saint-Pétersbourg). Les Bolcheviks ont repris le pouvoir dans le pays mais cet événement a déclenché la guerre civile en Russie. Les Bolcheviks n'étaient pas en mesure de continuer leurs batailles à la Première Guerre mondiale et, en 1918, ont signé un traité de paix séparé avec l'Empire allemand et l'Autriche-Hongrie, pour pouvoir se concentrer sur la guerre civile. L'Ukraine, à cette époque indépendante, a également signé un autre traité de paix séparé avec l'Allemagne et l'Autriche-Hongrie. Cela a ouvert une nouvelle phase dans la guerre entre la Russie et l'Ukraine que l'Ukraine a finalement perdue. 
